\title{
O RITMO E A INTERSEÇÃO DE CULTURAS NA OBRA AREIA II, DE ALEXANDRE LUNSQUI: INFLUÊNCIAS EM SEU PROCESSO COMPOSICIONAL
}

\author{
RHYTHM AND CULTURAL INTERSECTIONS IN \\ AREIA II, BY ALEXANDRE LUNSQUI: INFLUENCES \\ IN HIS COMPOSITIONAL PROCESS
}

Alexandre Lunsqui ${ }^{7}$ Universidade Estadual Paulista (Unesp) alunsqui@yahoo.com

Guilherme do Nascimento Davino Universidade Estadual Paulista (Unesp) guilhermedavino@yahoo.com.br 


\section{Resumo}

Este artigo pretende analisar aspectos rítmicos na obra Areia II, do compositor Alexandre Lunsqui. Analisamos as diversas influências rítmicas que ocorrem na obra, sejam elas vindas do repertório erudito, sejam oriundas de manifestações musicais externas a este repertório, como a música tradicional africana. $\mathrm{O}$ artigo mapeia as figuras rítmicas usadas na obra, contextualizando-as dentro das estratégias criativas empregadas pelo compositor.

Palavras-chave: Ritmo; música contemporânea; música tradicional africana; composição.

\section{Abstract}

This article intends to analyze rhythmic aspects in Areia II, by composer Alexandre Lunsqui. Whether they come from the classical repertoire, or from musical manifestations external to this repertoire, such as ethnic music, we analyze the different rhythmic influences occurring throughout the composition. The article maps out the rhythmic figures used in the work in relation to the creative strategies employed by the composer.

Keywords: Rhythm; contemporary music; traditional African music; composition.

\footnotetext{
1 Professor de composição na Universidade Estadual Paulista (UNESP). Estudou na Universidade de Campinas, University of lowa, Columbia University e no Institute de Recherche et Coordination Acoustique/Musique (IRCAM). Além de encomendas e prêmios no Brasil, recebeu prêmios da Guggenheim Foundation, American Academy of Arts and Letters, Koussevitzky, Harvard Fromm Foundation e do Ministério da Cultura da França. https://orcid.org/0000-0001-5776-9855 


\section{Introdução}

O uso do ritmo na música de concerto dos séculos $\mathrm{XX}$ e $\mathrm{XXI}$ tem sido motivo de debates bastante antagônicos. De um lado temos um grupo de compositores cuja rejeição ao ritmo aparece como condição para o estabelecimento de estéticas desvinculadas de "vícios" regressivos. O plano rítmico, para esse grupo, é tratado como elemento de conformidade: a mecanização do plano temporal, manifestado através do ritmo, enfraqueceria o texto musical. Esta crítica é sintetizada, em grande parte, pelos escritos de Theodor Adorno (1903-1969). Para o filósofo e compositor alemão, o plano rítmico age como elemento de enfraquecimento de outros parâmetros composicionais e estruturais de uma obra musical. Este pensamento, presente abertamente em suas críticas a Igor Stravinsky (ADORNO, 1974), ecoará não somente no pensamento musical de compositores da estatura de Pierre Boulez (1925-2016)3 e Karlheinz Stockhausen (1928-2007), mas também nas novas diretrizes estéticas propostas pela geração dos espectralistas Tristan Murail (1947) e Gerard Grisey (1946-1998). ${ }^{4}$

Do outro lado temos o grupo que tem no ritmo o elemento central de suas práticas musicais e que rejeita o radicalismo das transformações estéticas propostas pelo primeiro grupo. Estariam nesse grupo compositores bastante próximos da cultura popular, onde existe grande riqueza de ritmos de origens folclóricas. ${ }^{5}$ Foge do escopo de nosso trabalho uma discussão detalhada a respeito dessas duas posições antagônicas. Uma investigação como essa demandaria um estudo com orientações históricas, sociais e culturais, além de análises de posicionamentos críticos de ambos os lados. Portanto, ao invés de aprofundarmos a nossa análise sobre as origens e os desdobramentos do que entendemos ser uma polarização de atitudes em relação ao uso do ritmo na composição contemporânea, procuramos revelar a existência de uma outra visão que chamamos de estética inclusiva: compositores que incorporam o elemento rítmico na criação de novas obras, ao mesmo tempo que sustentam um direcionamento de tendências experimentais. Nesse caso, o uso de ritmos tradicionais como parte do tratamento temporal e estrutural das obras fornece uma palheta bastante grande de possibilidades e, consequentemente, de estéticas produzidas. Esta atitude para com o ritmo não vê necessidade de que se estabeleçam purismos estéticos notadamente caros aos dois grupos polarizados.

No decorrer do século XX, alguns compositores conseguiram incorporar matrizes rítmicas tradicionais em suas obras, ao mesmo tempo que desenvolveram uma individualidade estética inegável: desde Claude Debussy (1862-1918), influenciado pelo gamelão javanês Lesure (2013), passando por Béla Bartók (1881-1945), cuja música foi

3 As críticas de Boulez envolvem uma postura bastante controversa. Segundo ele, "qualquer civilização que conserve está fadada ao declínio porque tem medo de seguir em frente e atribui mais importância ao passado do que ao seu futuro" (BOULEZ apud PEYSER, 2005, p.119, tradução nossa).

4 Grisey não se despreende do conceito de ritmo totalmente, mas expressa a necessidade de se compor com durações derivadas da própria natureza do material sonoro, sem a austeridade e a artificialidade de pontos de referência (GRISEY, 1987, p.242).

5 Incluiremos nesse grupo compositores como o brasileiro Villa-Lobos (1887-1959), o americano Aaron Copland (1900-1990) e o argentino Alberto Ginastera (1916-1983). 
influenciada especialmente pela música folclórica húngara (GILLES, 2013), e Olivier Messiaen (1908-1992), influenciado pelo ritmo da música indiana (ŠIMUNDZA, 1987, p.117), até compositores como György Ligeti (1923-2006) (TAYLOR, 2003, p.83) e Steve Reich (1936) (SCHWARZ, 1981/1982, p.230), dois nomes icônicos na música do século XX. Tanto Ligeti quanto Reich tiveram grande interesse pelos ritmos de origem africana. Enquanto Reich é influenciado diretamente a partir de suas experiências musicais em Gana, em 1970, Ligeti procura reproduzir as polifonias encontradas na música de Uganda, da República Central Africana, do Malawi, da República dos Camarões, entre outras regiões da África. Eles encontram na polirritmia da música africana uma fonte abundante de possibilidades composicionais que não apenas ecoam as preocupações criativas já desenvolvidas por ambos, como também fornecem meios de significativa expansão criativa. Ao descobrir a música africana, Steve Reich já trabalhava em obras centradas em reiterações ou loops, como Violin Phase e Piano Phase, ambas de 1967. No caso de Ligeti, o trabalho de sobreposição de velocidades do compositor norte-americano Conlon Nancarrow (1912-1997) e elementos harmônicos e rítmicos do jazz terão grande influência em várias de suas obras.

Especificamente em relação às tribos africanas, os ritmos e os contrapontos altamente elaborados destes povos chamaram a atenção de musicólogos como Simha Arom (1930), o qual realizou importantes estudos e registros fonográficos sobre a música centro-africana. O fascínio dos músicos e musicólogos foi tanto que levou a Unesco a proclamar as tradições orais do povo aka como uma das obras-primas do Patrimônio Oral e Imaterial da Humanidade em 2003. Tais tradições continuam a chamar a atenção de compositores ao redor do mundo no século XXI.

As influências musicais provenientes de culturas exteriores à música de concerto contemporânea também podem ser observadas em compositores brasileiros como Roberto Victório (1959), que se utiliza de elementos da música ritual da etnia Bororo em suas composições (VICTORIO, 2003), e Eli-Eri Moura (1963), que explora estruturalmente elementos musicais de diversas manifestações populares brasileiras, como o maracatu e a capoeira (MOURA, 2006). Alexandre Lunsqui (1969), compositor cuja obra será analisada em nosso artigo, também se encaixa na categoria de compositores que navegam entre universos estéticos aparentemente distintos. Apesar da influência da música espectral em parte de suas composições, Lunsqui tem uma formação bastante eclética, passando pelo jazz e pela música brasileira. Numa combinação de influências, Lunsqui incorpora materiais musicais provenientes de diversas fontes externas à música de concerto em suas composições, seja em um ciclo de obras usando um instrumento emblemático como o berimbau, ${ }^{6}$ seja usando a estrutura rítmica do samba, como fez na peça Topografia Index 3A (LUNSQUI, 2008).

Em uma analogia com Steve Reich, que como percussionista mergulhou no universo da música africana como intérprete antes de incorporá-la e desenvolvê-la em sua própria linguagem criativa, a especial atenção de Lunsqui para com estruturas rítmicas é, ao menos em parte, decorrente de sua própria experiência como pianista de jazz e 
música brasileira no final dos anos 1980 e nos anos 1990. Com relação a György Ligeti, Lunsqui mantém uma relação de reverência ainda maior: ao escutar os Estudos para Piano e o Concerto para Piano do compositor húngaro pela primeira vez, no início dos anos 1990, Lunsqui teve uma experiência reveladora: estava diante de obras radicais que não se curvavam a dogmas estéticos e muito menos soavam como estereótipos de outras culturas.

Lunsqui atesta que, dentro da complexa pluralidade de parâmetros que são operados em uma obra, "o ritmo é uma das forças mais diretas na música" (LUNSQUI, 2008, p.12, tradução nossa). A ideia de força é entendida aqui de duas formas: a primeira no sentido literal de agente físico que possui capacidade de alterar um estado de repouso ou movimento de um objeto (e, no caso da música, o objeto passa a ser o som); a segunda como estrutura de memória, ou seja, agente de "base", elemento de referência que pode ser moldado a partir da alteração de suas durações internas ou servir de base para inserção de agregados harmônicos, perfis melódicos (temáticos ou não) e desenvolvimento de camadas e texturas. É justamente essa força cultural e estética, aliada ao referencial de memória inerente a um padrão rítmico, que o torna elemento de debates e polarizações como os descritos acima.

Em sua obra Areia II (2008), Lunsqui une elementos musicais de três culturas distantes e que são parte integral de sua trajetória como músico. São elas o terceiro movimento da obra inacabada de Arnold Schoenberg, que ficou conhecida como Três Peças para Orquestra de Câmara, a música Surfboard,7 de Antônio Carlos Brasileiro de Almeida Jobim, e uma canção tradicional do povo aka chamada Yangissa. Areia Il é uma continuação da obra Areia, composta em 2006 para um projeto em que Lunsqui participou chamado Schoenberg Revisited, organizado pelo grupo alemão Ensemble Piano Possibile. A proposta era para que a obra inacabada de Schoenberg fosse usada livremente, sem regras específicas. Essa foi a oportunidade de unir o material do mestre alemão com a música de outras culturas que eram de interesse do compositor brasileiro.

Tendo em vista a insuficiente bibliografia em língua portuguesa sobre os aka, julgamos necessário dar uma atenção especial aos seus costumes musicais e culturais, trazendo mais informações sobre este povo. Sendo assim, relacionaremos as informações adquiridas sobre Areia I/ através dos estudos de Simha Arom sobre o ritmo e a estruturação na música tradicional da região central do continente africano, com informações obtidas através de seu livro African polyphony and polyrhythm: musical structure and methodology (1991). Buscaremos encontrar semelhanças entre a organização rítmica nas manifestações musicais do povo aka e o tratamento rítmico usado por Lunsqui em sua composição.

7 O compositor revela que o título Areia llé uma imagem proveniente da palavra Surfboard, título da canção de Tom Jobim que serve como fonte de material rítmico utilizado na obra. 


\section{Yangissa e Areia II}

Segundo Daniel Joseph Duke (2001), apesar de alguns pesquisadores convencionarem e usarem extensivamente o termo aka para designar tanto essa população quanto sua língua, eles, por sua vez, se autointitulam bayaka ou baaka. Para este trabalho, seguimos a convenção com o nome aka. Os aka fazem parte de um grupo de populações conhecidas amplamente, em parte pejorativamente, como pigmeus. ${ }^{8} \mathrm{O}$ termo pigmeu deriva da palavra grega Пuүuaíoc, chegando ao português através do latim pygmaeus, significando um côvado. ${ }^{9}$ Segundo Susanne Fürniss (2006), atualmente este termo "refere-se a vários grupos étnicos diferentes que vivem ao longo da linha do equador no continente africano e falam línguas de diferentes famílias linguísticas" (FÜRNISS, 2006, nota de rodapé, p. 2, tradução nossa). Entre os critérios usados para agrupar esses povos estão a pela escura e pequena estatura, sendo originalmente caçadores-coletores. ${ }^{10}$ Os aka se localizam na floresta tropical africana, em ambos os lados da fronteira entre a República Centro-Africana e a República Popular do Congo. São falantes da língua aka, uma língua bantu classificada pela NUGL (New Updated Guthrie List) como parte do grupo Bantu C104 (MAHO, 2009, p.25). Originalmente eram nômades que viviam da caça, da coleta de alimentos provenientes da floresta tropical e da troca de alimentos com agricultores locais. No entanto, estão se tornando cada vez mais sedentários e vivendo em parte de sua própria agricultura (BAHUCHET, 1989).

Como resultado de seu passado nômade e caçador, os aka possuem poucos instrumentos, todos de pequeno porte, como arcos com uma ou duas cordas, pequenos tambores, uma espécie de cítara-harpa, lâminas de ferro e flautas. Toda a música aka é cantada, com ou sem acompanhamento instrumental, e está quase sempre ligada a eventos sociais, à caça e à vida religiosa e espiritual da comunidade. Sobre a música aka, Simha Arom (1973) diz que

A música dos $A k a$ é essencialmente vocal. É caracterizada pela predominância de uma polifonia que é geralmente altamente complexa, e pelo uso de uma técnica de emissão vocal que, como o princípio do yodel, consiste na alternância entre voz de peito e voz de cabeça. (AROM, 1973, texto do encarte, tradução nossa).

Sobre a relação do fazer musical aka e sua espiritualidade, Bahuchet (1995, p.59, tradução nossa) diz que "os $A k a$ apresentam um exemplo extremo, onde a religião se expressa quase exclusivamente através da música e da dança, sem oficiante, sem oração e sem ofertas, ou seja, sem qualquer gesto religioso perceptível".

8 Sobre a invenção do conceito de "pigmeu", ver Bahuchet (1993)

9 Medida baseada no comprimento do antebraço, da ponta do dedo médio até o cotovelo. Muito usada em civilizações antigas. 
Em Areia II, Lunsqui utilizou-se de uma figura rítmica ${ }^{11}$ proveniente de uma canção aka chamada Yangissa, ${ }^{12}$ Yangisa Yanga Tae ${ }^{13}$ ou Yàngísà. ${ }^{14}$ Lunsqui se interessou por esta canção após ouvir o CD intitulado African Rhythms, um projeto do pianista Pierre-Laurent Aimard, em que músicas tradicionais dos aka são dispostas lado a lado com obras dos compositores György Ligeti e Steve Reich. O projeto ressalta as influências que ambos os compositores receberam das manifestações e modelos musicais oriundos da África Subsaariana, como mencionamos anteriormente. Yangissa, ${ }^{15}$ umas das canções do repertório aka que tem por função a coesão do grupo, é cantada com o auxílio de um instrumento de duas cordas chamado èngbítí, tocado e feito quase exclusivamente pelas mulheres aka. A figura rítmica escolhida por Lunsqui, a qual nomeamos de $A 3,{ }^{16}$ é executada no èngbítí do início ao fim da canção.

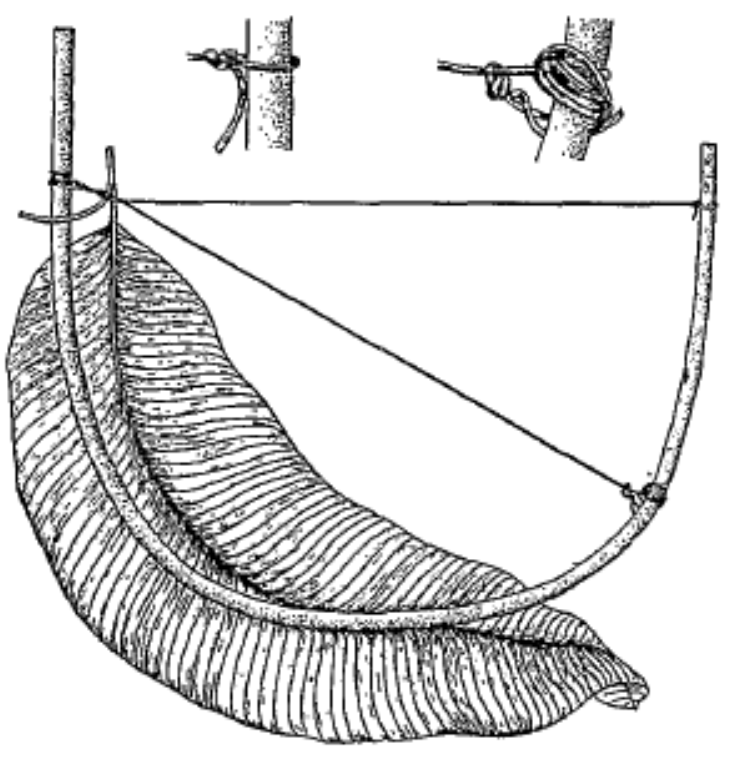

Fig. 1: Ėngbití. Fonte: Dehoux e Guillaume (1995).

A figura rítmica $\mathrm{A} 3$ tem uma constituição bastante peculiar: inicialmente temos um breve ataque seguido de uma respiração. Um segundo segmento, mais longo (formado por seis semicolcheias), cria uma sensação de percurso homogêneo interrompido por outro breve silêncio (uma semicolcheia). O ostinato termina com a adição de três pulsos que se conectam ao primeiro ataque isolado. Ao agruparmos essas durações (incluindo as pausas), temos um grupo de cinco semicolcheias seguido por um grupo de sete semicolcheias. Uma segunda camada rítmica emerge desses dois agrupamentos: um

\footnotetext{
11 Para ver a definição de figura rítmica neste trabalho, ver parágrafo 4 do subcapítulo 3.1.

12 Título usado no CD African Rhythms (2003), segundo texto de encarte feito por Simha Arom e Stefan Schomann (AROM, 2003). Adotamos este título para este trabalho.

13 Título usado no CD Centrafrique. Pygmées Aka. Chants de chasse, d'amour et de moquerie (1998). Tradução: Chame, chame seu pai, segundo texto de encarte feito por Sussane Fürniss (1998).

14 Título usado no artigo "Chasse, sexualité et musique. Un arc musical des Pygmées Aka" (DEHOUX) e cujo significado seria somente um ideofone para o som de uma abelha forrageando.

15 Link para a gravação da obra: https://www.youtube.com/watch?v=CG20vWqvgFw.

16 Ver Quadro 1 (Figuras rítmicas)
} 
pulso ternário subjacente que na gravação dos aka é revelado com o bater das palmas das mãos. Por detrás de uma aparente simplicidade, a figura rítmica A3 possui interpretações distintas não somente em sua codificação em notação musical, mas também no entendimento de sua morfologia. É justamente essa volatilidade e flexibilidade do material que chama a atenção de Lunsqui.

O uso das figuras rítmicas será mostrado através de exemplos tirados da partitura. Ainda que não seja feita uma análise da estrutura de cada uma das figuras utilizadas na obra, apontamos como o compositor entende cada figura como sendo um pequeno sistema que opera dentro de suas particularidades de sons e silêncios. Nesses sistemas, as quantidades de células básicas (no caso de A3, são doze semicolcheias) e as sensações de velocidades oriundas da figuras revelam potencialidades de transformação dentro de um contexto estrutural maior, onde cada figura pode assumir "roupagens" timbrísticas, harmônicas e melódicas das mais variadas.

\section{Gehende Viertel e Areia II}

Gehende Viertel é o nome do terceiro e último movimento da obra inacabada de Schoenberg conhecida como Três peças para Orquestra de Câmara, composta em fevereiro de 1910. Gehende Viertel é o único movimento inacabado e é também o movimento em que o caráter rítmico ganha maior destaque. No início deste movimento encontra-se a indicação de andamento Contínuo (Gehende) seguido por uma semínima (Viertel). Um acorde composto por quartas sobrepostas é sustentado no órgão, ou harmônio, durante os oito primeiros compassos do movimento. Ostinatos desempenham um papel bastante importante em Gehende Viertel e servem de contraponto à estaticidade do acorde de quartas sobrepostas. Dentro do projeto de interseção de culturas, os ostinatos são um outro ponto de contato com a obra Areia II.

A figura rítmica $A 1^{17}$ e o contínuo métrico $a^{18}$ são os dois componentes provenientes de Gehende Viertel que serão essenciais na construção de Areia II. A1 (retângulo vermelho) é derivada do ostinato feito pela flauta a partir do quinto compasso de Gehende Viertel. O contínuo métrico a (retângulo azul), por sua vez, é formado pela junção do ostinato feito pelo contrabaixo a partir do sétimo compasso, seguido pelo gesto ascendente do clarinete no oitavo compasso.

\footnotetext{
17 Ver Quadro 1 (Figuras rítmicas).

18 Ver Quadro 2 (Exemplos de contínuos métricos e suas transformações).
} 


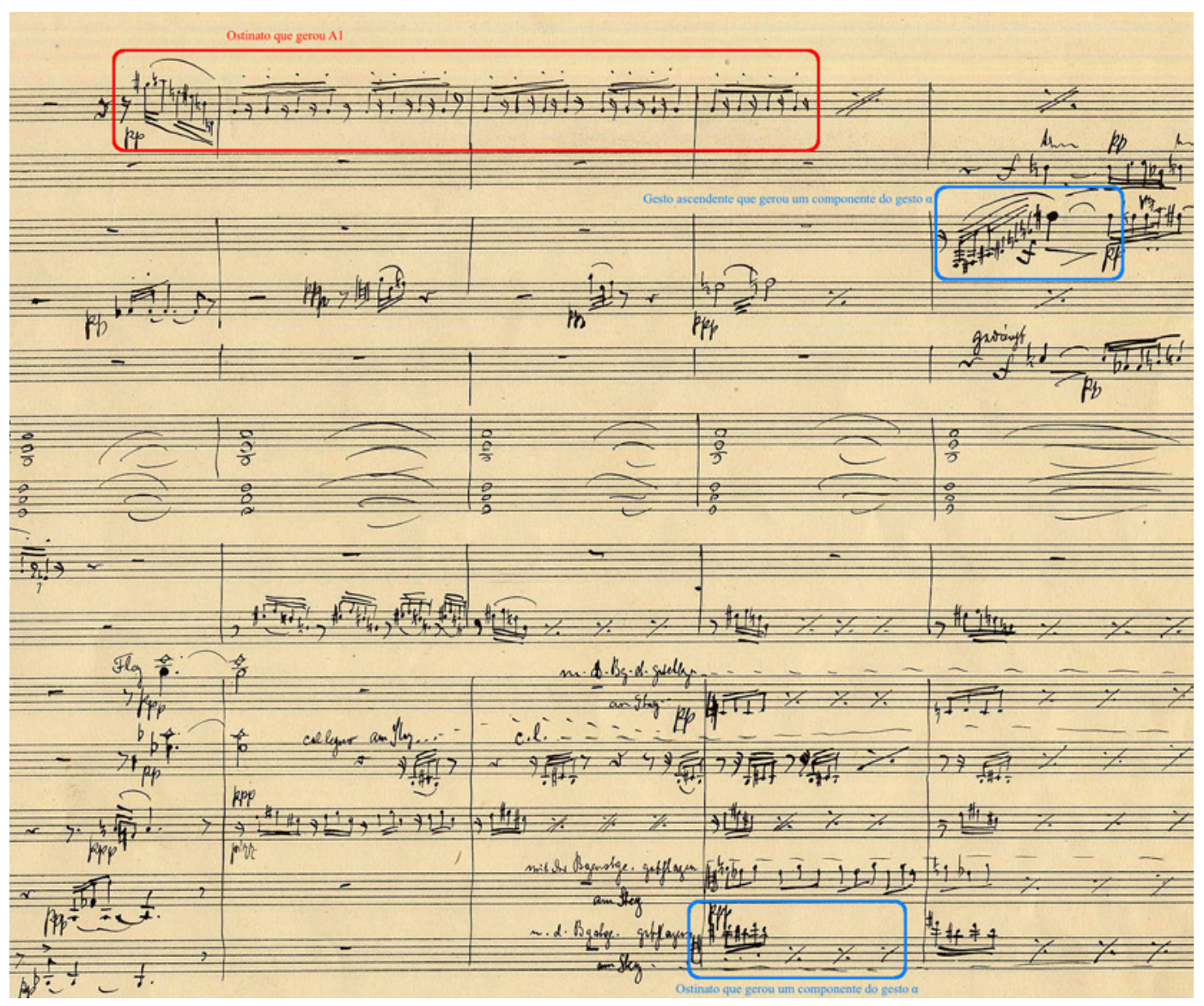

Fig. 2: Material proveniente de Gehende Viertel utilizado por Lunsqui em Areia II.

Outros procedimentos relacionados ao uso do material proveniente de Schoenberg em Areia Il serão discutidos no decorrer do trabalho.

\section{Surfboard e Areia II}

Surfboard foi lançada no álbum The wonderful world of Antonio Carlos Jobim em 1965, composta por Tom Jobim e arranjada por Nelson Riddle (1921-1985), sendo a única música instrumental do álbum. $O$ interesse musical de Lunsqui pela música Surfboard surgiu na época em que tocava piano em um grupo de música brasileira. Lunsqui utilizou-se de um trecho do primeiro tema da música para criar a figura rítmica que chamaremos B2, ${ }^{19}$ mantendo seu caráter melódico descendente. Veremos também que Lunsqui faz uso da presença de dois tempi paralelos em Surfboard e utiliza esse tipo de relação temporal entre diferentes camadas na estruturação de Areia II. A justaposição de camadas temporais distintas será discutida juntamente com a descrição das figuras rítmicas no decorrer do trabalho. 


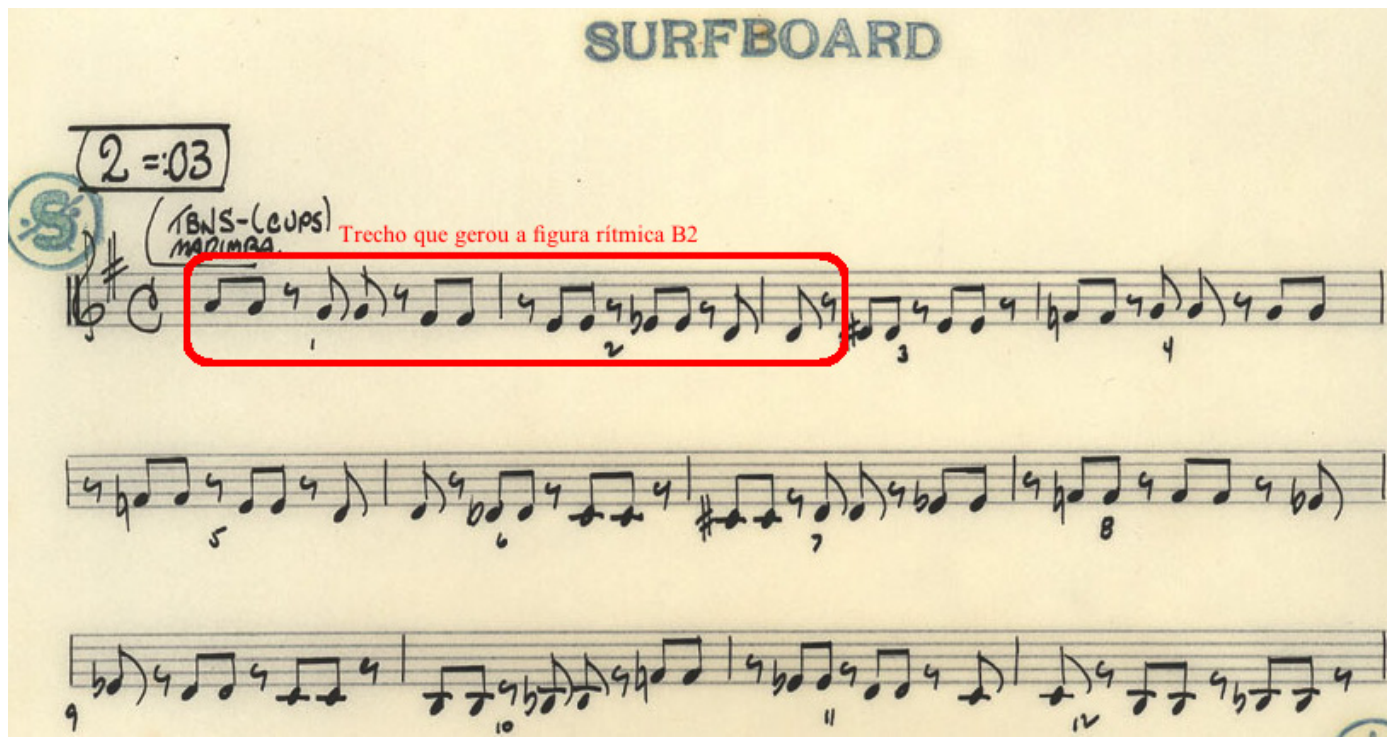

Fig. 3: Material proveniente de Surfboard utilizado por Lunsqui em Areia II. ${ }^{20}$

\section{Figuras rítmicas em Areia II: hierarquia e sinergia}

Areia II foi composta em 2008 e possui a seguinte formação: flauta, clarinete em $\mathrm{Bb}$ alternando com clarone, trompa em $\mathrm{F}$, trompete em $\mathrm{Bb}$, percussão múltipla (um percussionista), piano preparado, harpa, violino, viola e violoncelo. Em Areia II, o ritmo se configura como principal elemento articulador do discurso musical. A análise do ritmo na obra será feita a partir do mapeamento de padrões que chamamos de figuras rítmicas. Por figura rítmica compreendemos ser o esqueleto rítmico e acentual subjacente a um gesto musical em ostinato. Segundo Arom (1989), para que uma sequência de durações se configure como uma figura rítmica, ela precisa ter pelo menos um desses três componentes: acentuação, mudança de timbre e/ou altura e alternância de durações. Uma sequência de valores iguais, não acentuados, sem diferenciação de timbre, como as sequências ilustradas no Quadro 2, recebe a definição de um contínuo métrico (AROM, 1989, p. 93).

As diferenças entre figura rítmica e contínuo métrico tornam-se menos distintas quando o material rítmico passa por processos de transformações variados. Por exemplo, o compositor pode aplicar acentuações assimétricas em um contínuo métrico. Nesse caso teríamos um elemento híbrido entre figura e contínuo métrico. Para a análise do material rítmico de Areia II, optamos por manter as diferenciações estabelecidas por Simha Arom, mesmo entendendo que a obra de Lunsqui situa-se em um território de hibridizações de procedimentos composicionais.

Percebemos que em cada uma das seções de Areia II uma figura rítmica se sobressai, seja por apresentar um período ${ }^{21}$ maior, seja por se destacar timbristicamente.

\footnotetext{
20 Fonte: Manuscrito do arranjo feito por Nelson Riddle.

21 Entendemos como período "um círculo temporal baseado na repetição de eventos similares em intervalos semelhantes" (MOLES, 1968 apud AROM, 1989, p.91, tradução nossa).
} 
Nomeamos essas figuras de figuras rítmicas guias. Mapeamos o aparecimento dessas figuras e analisamos como foram utilizadas no aspecto estrutural da peça. Por exemplo, nota-se que a figura rítmica A1 está estatisticamente mais presente no decorrer da peça e que ela se configura como elemento referencial por mais tempo. Este mapeamento resultou em um quadro fundamental para entendermos a utilização de padrões rítmicos de referência no desenvolvimento estrutural de Areia II. Pode-se dizer que compositor esculpe o material sonoro a partir da presença (ou ausência) dos elementos rítmicos de referência. A esses elementos estão subordinadas importantes decisões composicionais envolvendo articulações formais, blocos de harmonias, densidades, tipos de perfis melódicos, entre outras.

Fundamental na estrutura de Areia /l é o uso de justaposições. Cortes bruscos e mudanças de figuração são encontrados com abundância na obra. Esse tipo de distribuição do material sonoro faz com que as estruturas sejam reveladas de uma forma bastante direta e transparente. Comparando esse tipo de tratamento com a arquitetura, é como se as componentes internas de um edifício (tubulações, fiações elétricas, estruturas de sustentação etc.), estivessem aparentes, sem as camadas subsequentes não mais essenciais para a sustentação da construção. Na engenharia da obra, a maioria das seções é justaposta de maneira bastante dinâmica, sem a preocupação de preparações que, na visão do compositor, poderiam atenuar a carga cinética que caracteriza a peça. É importante dizer que, ainda que as seções sejam justapostas no decorrer da peça, há um controle preciso das separações entre elas. O compositor trabalha relações de causa e efeito com bastante rigor. O uso da ruptura como tratamento do material, seguido pela introdução de uma nova figura rítmica guia e/ou pela ressignificação de uma ou mais figuras rítmicas já presentes, cria o dinamismo das relações de causa e efeito. Para que haja um controle preciso dessas relações de consequência, o compositor estabelece funções bem definidas para cada instrumento. As diversas camadas sonoras e suas respectivas trajetórias dentro de cada seção seguem construções internas de natureza plural: podem ser construções rítmicas, diferentes tipologias sonoras organizadas pela similaridade de gestos e/ou similaridade de envelopes dinâmicos, harmonias predominantes (notas pedais) e, finalmente, itinerários melódicos. O rigor da funcionalidade atribuída a cada uma das construções internas de Areia II é que delineia a forma da obra.

A peça é dividida em duas partes de características bastante distintas. A primeira parte possui oito seções e a segunda parte tem nove seções, sendo que as duas últimas exercem um papel de Coda e Codetta, respectivamente. Os inícios de seções quase sempre apresentam uma ou mais figuras rítmicas acompanhada(s) de mudanças texturais e/ou timbrísticas significativas. Neste sentido, existe uma convergência entre transformações de ordens diferentes: timbres/texturas estão alinhados a mudanças de figuras rítmicas. Essa conjunção de mudanças esculpe o material sonoro ao longo da peça e, consequentemente, a sua forma. Mesmo as duas últimas seções de Areia II, as quais apresentam um comportamento distinto, sem nenhuma figura rítmica, possuem blocos texturais peculiares que fortalecem o delineamento formal do final da peça. Ou seja, ainda que o ritmo seja o motor da obra, ele é apresentado dentro de um sistema de 
coordenadas harmônicas, melódicas e texturais que estabelecem a sinergia do sistema já mencionado anteriormente.

Uma análise harmônica mais completa está fora do escopo deste trabalho. Em linhas gerais, a harmonia de Areia /l é baseada na análise espectral de um pequeno trecho da canção Yangissa. A análise espectral foi feita com a ajuda dos softwares AudioSculpt e OpenMusic, ambos desenvolvidos pelo Ircam (Institut de Recherche et Coordination Acoustique/Musique), onde Lunsqui estudou durante um ano. O material gerado pela análise foi amplamente filtrado de forma intuitiva. Foram isoladas algumas frequências que atuam como elementos fixos ao longo da peça, bem como base na criação de agregados harmônicos, os quais são dotados de timbres característicos. Um exemplo do uso de notas fixas pode ser visto nas três primeiras seções da peça. Os instrumentos de cordas utilizam principalmente as alturas F, Eb, E (1/4 de tom acima) e C\#.

Um outro procedimento harmônico usado pelo compositor faz uso dos perfis melódicos de duas matrizes sonoras utilizadas. No caso de Surfboard, um simples perfil melódico descendente funciona como importante modelo morfológico que será "orquestrado" pelo compositor. O mesmo ocorre com pequenos recortes melódicos da obra de Schoenberg. O material é verticalizado e serve de base para construções harmônicas. Normalmente, o compositor "cruza" o material harmônico com a morfologia rítmica. A partir disso, uma série de operações de transformação é aplicada. Por exemplo, na seção final da peça (Fig. 5), os agregados são dissolvidos em rápidos gestos ascendentes e descendentes. É como se um perfil de Surfboard fosse expandido verticalmente (aumento do âmbito do perfil) e multiplicado por um fator de velocidade bastante grande.

Abaixo, temos dois exemplos de material harmônico em Areia II. No primeiro caso (Fig. 4), o movimento descendente de Surfboard gera uma sequência de três agregados ou três fases: primeiro nos sopros, imediatamente seguido no piano, harpa e percussão, e finalmente uma nova configuração em tercinas nos sopros e na percussão. No $2 \circ$ e 3 agregados, nota-se o elemento microtonal presente na harpa, no clarinete e no trompete. É uma forma de preservar elementos originários da análise espectral de Yangissa (normalmente organizada com a precisão de quartos de tom). No segundo exemplo (Fig. 5), a harmonia é dissolvida na confluência de gestos ascendentes e descendentes. Essa estratégia de dissolução do material harmônico através de flashes sonoros ou rápidos gestos é um modelo estrutural utilizado repetidas vezes na seção final de Areia II. 


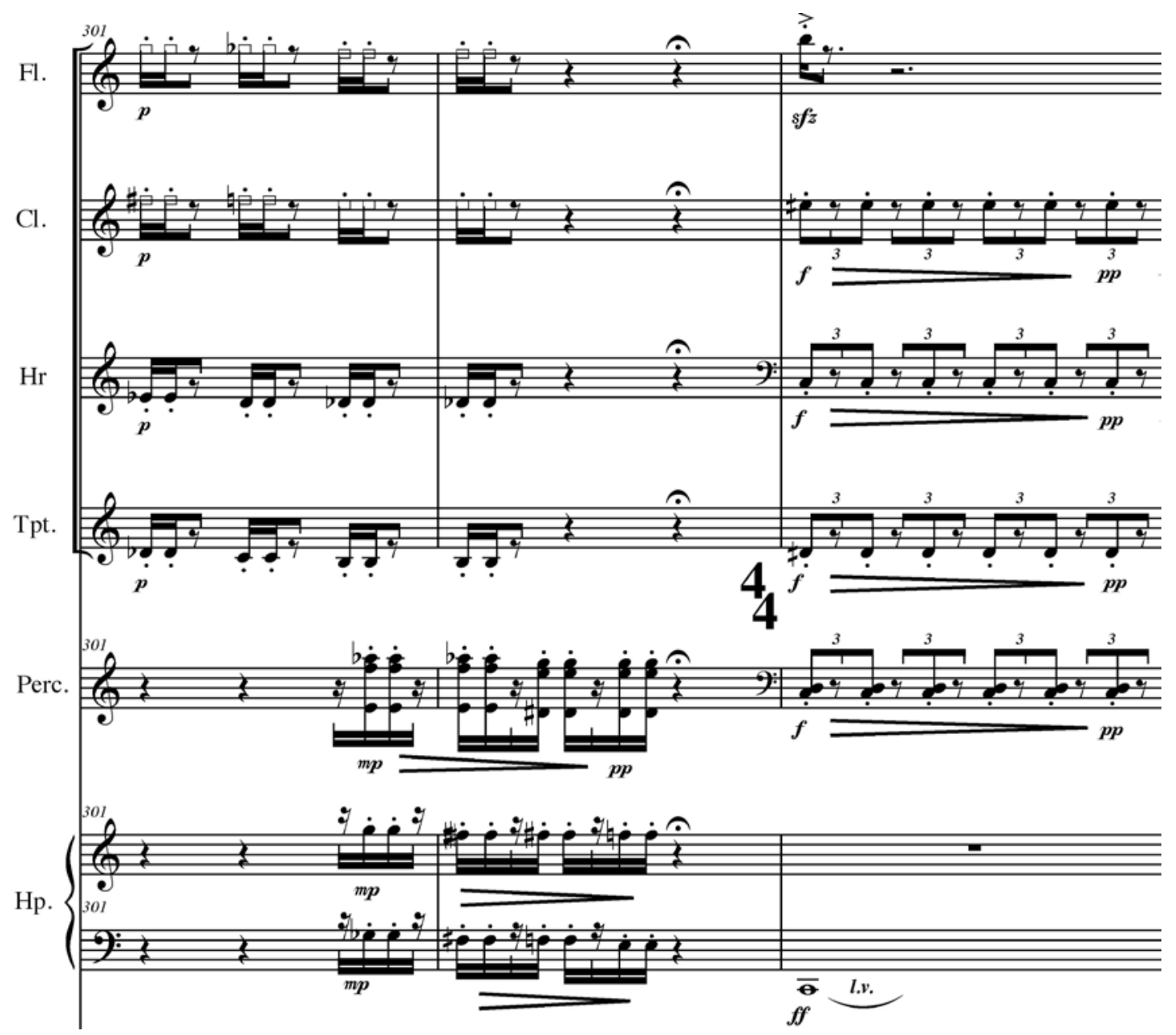

Fig. 4: Agregados harmônicos utilizados em Areia Il.

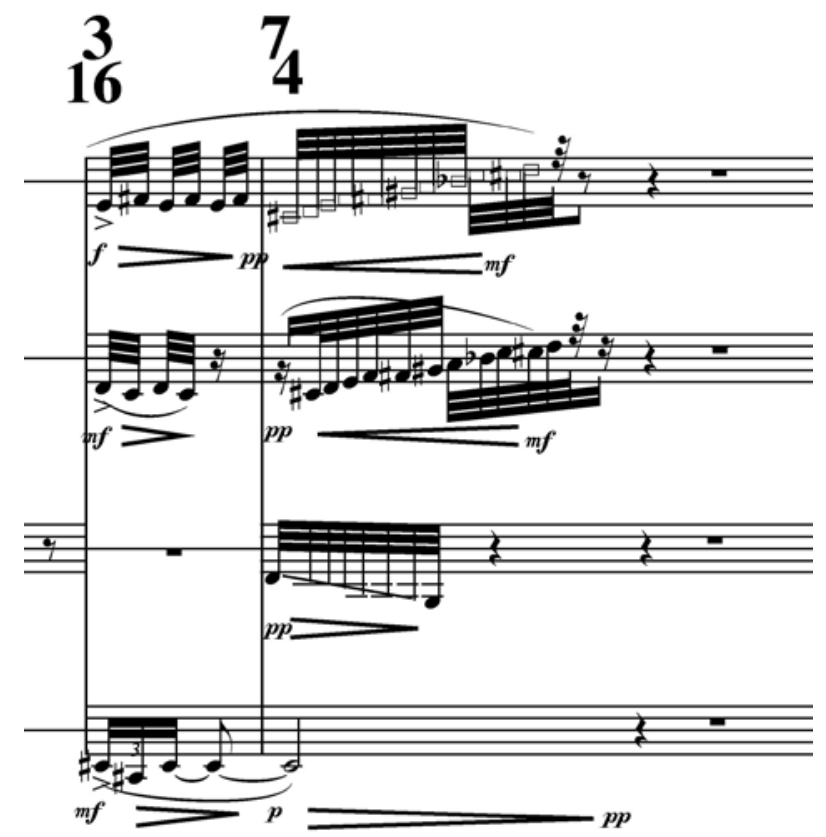

Fig. 5: Procedimento de dissolução do material harmônico (seção final de Areia II). 
Os Quadros 1 e 2 contêm as figuras rítmicas e os contínuos métricos usados no decorrer da obra. Para facilitar a análise, as figuras foram divididas de A1 a A6 (tendo uma mesma matriz rítmica), B1, B2, C1, D1, E1 e E2. Já os dois contínuos métricos usados (a e $\beta$ ) e suas respectivas transformações (as quais são simples alterações, como filtragens ou mudanças de velocidades do contínuo métrico) estão no Quadro 2. Vale ressaltar que a ausência de acentuação é um dos principais parâmetros de diferenciação entre a categoria de figura rítmica e de contínuo métrico.

\begin{tabular}{|c|c|c|c|}
\hline \multicolumn{4}{|c|}{ Figuras rítmicas } \\
\hline A1 & F) $A \%$ A\% $A \%$ A\% & $\mathrm{A} 2$ & Pl \\
\hline A3 & & A4 & $>\quad \underline{=} \stackrel{6}{=}=\frac{6}{=}$ \\
\hline A5 & - & A6 & \\
\hline B1 & & B1 & $H: \dot{\infty} \quad \%$ \\
\hline $\mathrm{C} 1$ & & D1 & $\# 9$ \\
\hline E1 & 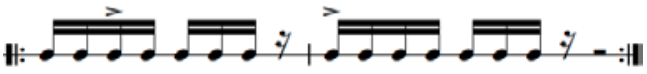 & E2 & I. \\
\hline
\end{tabular}

Quadro 1: Figuras rítmicas utilizadas em Areia Il.

\begin{tabular}{|c|c|}
\hline Contínuo Métrico a & Transformação do Contínuo Métrico a \\
\hline Contínuo Métrico $\beta$ & Transformação do Contínuo Métrico $\beta$ \\
\hline & 0
\end{tabular}

Quadro 2: Exemplos de contínuos métricos.

A maneira gradual como a figura rítmica A1 é expandida através do aumento do número de intervalos utilizados no início da obra elucida como o compositor trabalhou a expansão intervalar em sua composição. O compositor emprega duas técnicas de derivação da harmonia: resumidamente, são criadas curvas harmônicas a partir de transposições e da ideia de direcionalidade do material. As transposições podem ser observadas na forma como uma mesma figura rítmica é apresentada com diferentes alturas ao longo da obra. Exemplos de direcionalidade são encontrados tanto nos cromatismos 
descendentes das figuras B1 e B2 como nos blocos texturais em que as cordas realizam glissandos de forma bastante pronunciada.

Na primeira seção da peça, a figura rítmica A1 tem um papel de destaque, sendo o ritmo-guia em toda a trajetória inicial da obra. Essa figura é proveniente do terceiro movimento das Três peças para Orquestra de Câmara, de Arnold Schoenberg. Ela é introduzida no primeiro compasso pelo piano e pela flauta simultaneamente, porém só o piano segue com uma repetição sistematicamente regular por alguns compassos, onde as repetições começam a apresentar algumas variações como mudança de algumas alturas ou supressão de notas gerando um deslocamento métrico da figura. É importante ressaltar que a região da tessitura do piano onde A1 está sendo realizada está abafada por borrachas, uma preparação do instrumento para que atue de forma mais percussiva na obra. A figura rítmica A1 se caracteriza por um ataque acentuado seguido por semicolcheias entre pausas de semicolcheias com um sinal de decrescendo. É como se as semicolcheias subsequentes fossem "ecos" do primeiro ataque, como indicado algumas vezes pelo compositor na partitura. Podemos dizer que a figura rítmica A1 possui uma morfologia que será aproveitada como estratégia composicional em outros aspectos da obra. O modelo de um "eco" sonoro presente em A1 será usado em diversas seções de Areia II, mesmo na ausência da figura rítmica em si.

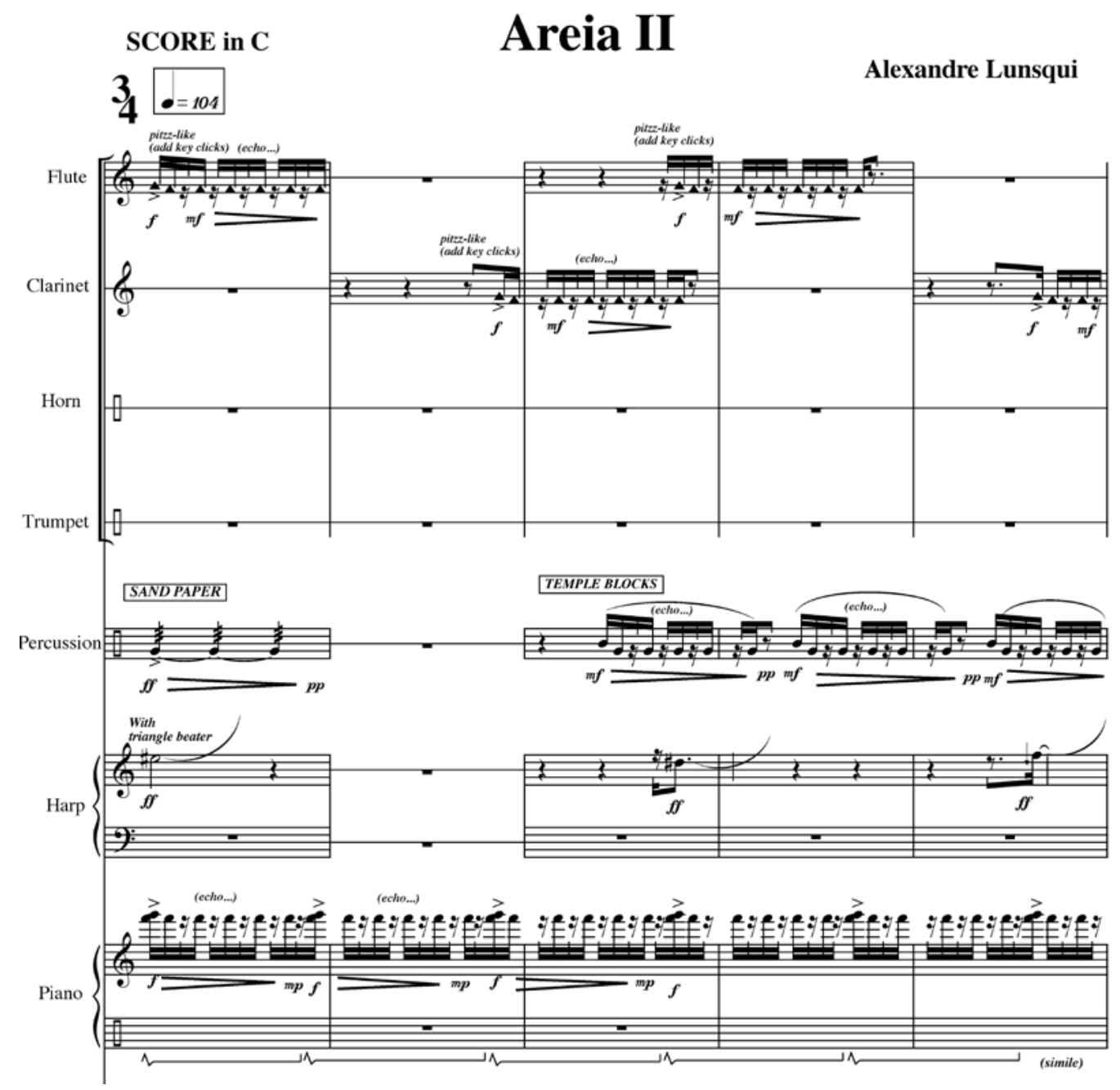

Fig. 6: Figura rítmica $A 1$. 
O início da obra revela boa parte das estratégias usadas pelo compositor em toda a peça. A percussão funciona tanto como "combustão" inicial quanto elemento de ressonância. O uso de espacialização também está presente com a figura A1 sendo multiplicada em vários pontos do ensemble. Como já dissemos, a estratégia de distribuição do material referencial e diversos pontos do ensemble será uma estratégia comum na obra. A harpa, por sua vez, reforça as acentuações da figura rítmica enquanto apresenta um glissando ascendente, uma sonoridade que será explorada em diversas configurações.

Uma nova figura rítmica bastante simples (A2) é apresentada pela trompa. A figura privilegia o espaço de silêncio entre dois ataques percussivos da trompa. A figura sofre variações no decorrer da primeira seção. Por exemplo, o ataque inicial em semicolcheia é deslocado para frente, assim, a figura que antes consistia em ataques duplos, sucessivos em semicolcheia, separados por três colcheias de pausa, agora são separados por somente duas.

O simples deslocamento do acento na estrutura rítmica revela uma das estratégias do compositor: a mera alteração do ataque inicial de um padrão previamente estabelecido será suficiente para criar um novo dinamismo entre as figuras rítmicas estabelecidas. Da mesma forma, o timbre e as técnicas estendidas atuam como operadores que atuam na criação de novas variações e, consequentemente, propulsionam o desenvolvimento horizontal e vertical da obra.

Uma nova figura (A3), coletada da canção Yangissa, permeia o restante da primeira seção. A3 possui características de movimento bastante interessantes. Após o ataque, há uma pequena pausa que propulsiona o material sonoro até o acento da última semicolcheia. Essa pequena engrenagem será explorada através de variações de timbre, espacializações e justaposições já mencionadas. Em Yangissa, a figura também funciona como propulsora de um complexo rítmico constituído por diversas camadas sonoras.

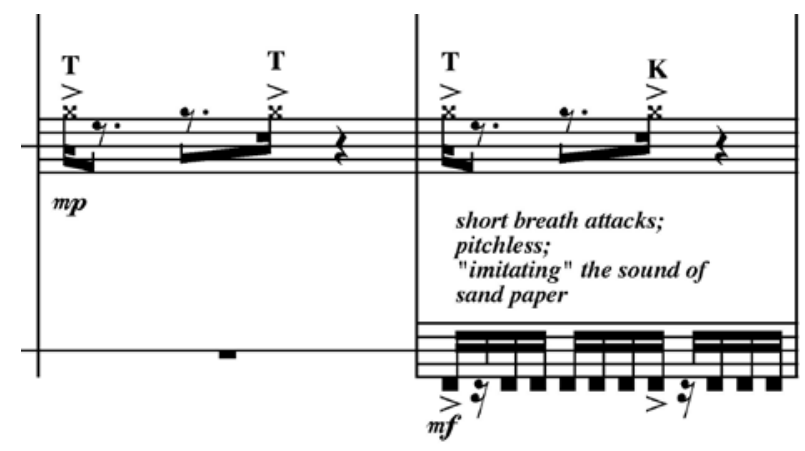

Fig. 7: Figura rítmica A2 (linha superior) e A3 (linha inferior).

A figura rítmica A4, que consiste em uma sequência de dezesseis ataques com acento na primeira e na nona nota, é introduzida pelo piano numa configuração de semicolcheias. A figura é transformada em sextinas logo depois, ainda dentro da tessitura abafada por borrachas. Observamos aqui uma operação de mudança de velocidade enquanto o timbre permanece inalterado. A percussão, através dos temple-blocks, também é alterada para sextinas. Temos aqui a ideia de um metainstrumento: piano e percussão conectados, mantendo a mesma trajetória rítmica, porém com velocidades flutuantes. Um complexo timbre emerge da união entre o piano preparado e a percussão. 


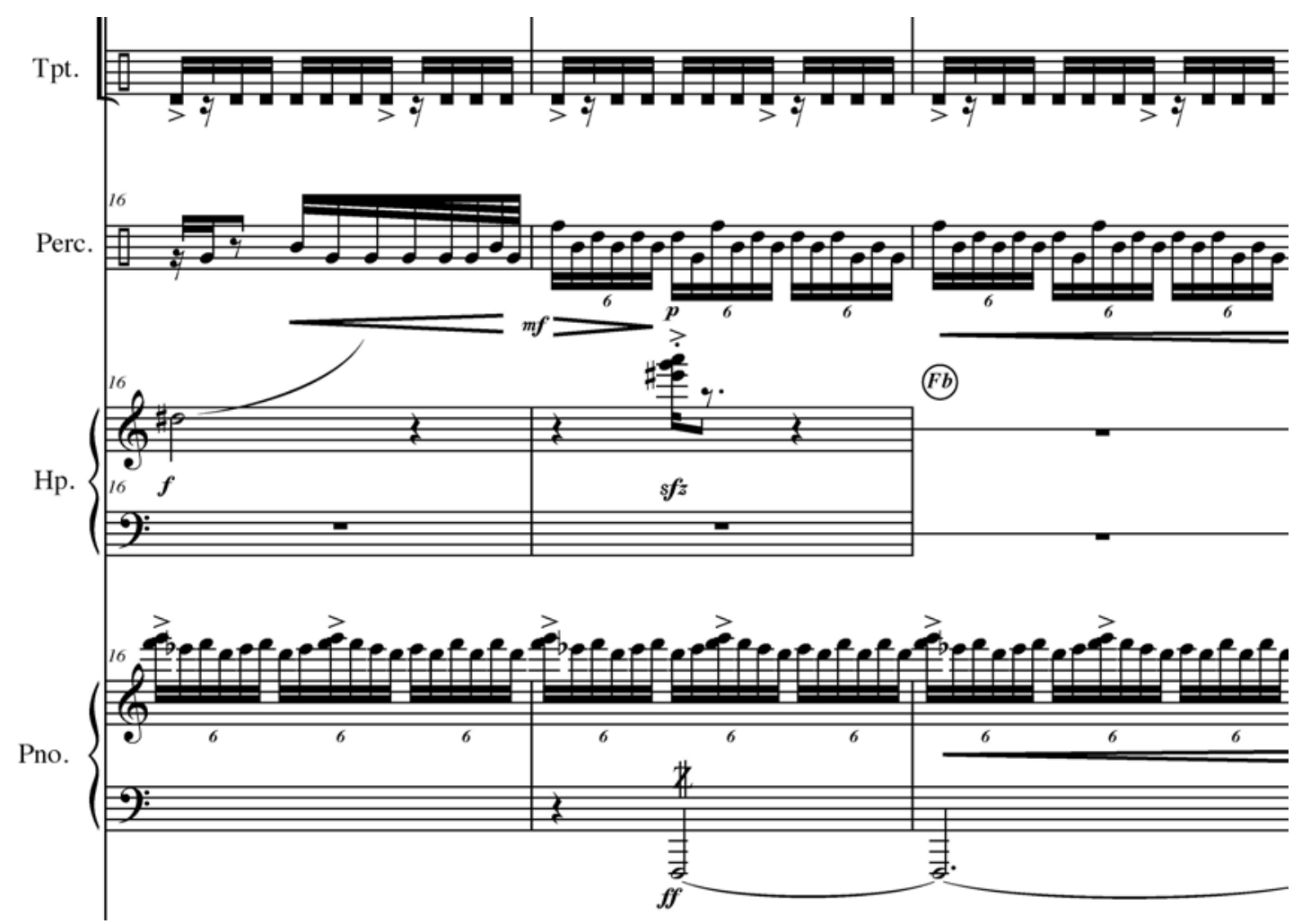

Fig. 8: Figura rítmica A4 (piano e percussão como um único instrumento).

A figura rítmica A5 é caracterizada por um glissando tocado com uma pedra de mármore nas cordas do piano. Trata-se de uma transformação bastante peculiar da figura A1 e que detém uma sonoridade oriunda do ataque da harpa no primeiro compasso. O modelo de ataque seguido de glissando é agora transformado e esculpido pelo piano através de uma configuração específica.

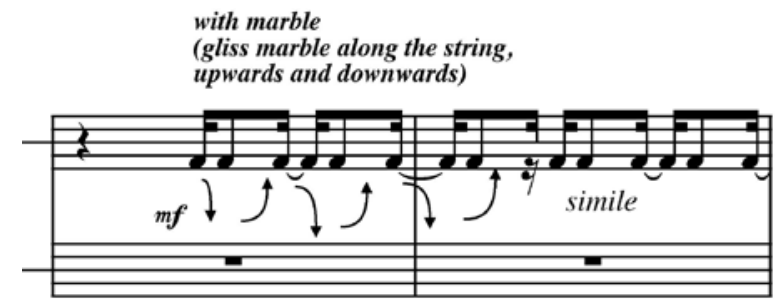

Fig. 9: Figura rítmica A5

A última figura rítmica da primeira seção é $A 6$, apresentada com rápidos golpes de ar pelo clarinete. Trata-se de uma derivação da figura A3, extraída do povo aka. Em A6, temos uma transformação bastante simples: ao invés do ataque inicial, cinco semicolcheias precedem um pequeno ataque em staccato. $O$ mesmo tipo de configuração, mas com apenas três semicolcheias seguidas por outro staccato, forma a segunda parte da figura A6. Esta configuração possui uma conotação de direcionalidade bastante definida, uma vez que é criada uma clara sensação de duas "chegadas" ou dois "alvos" internos à figura. Existe, portanto, uma componente cinética bastante forte inerente à figura. 


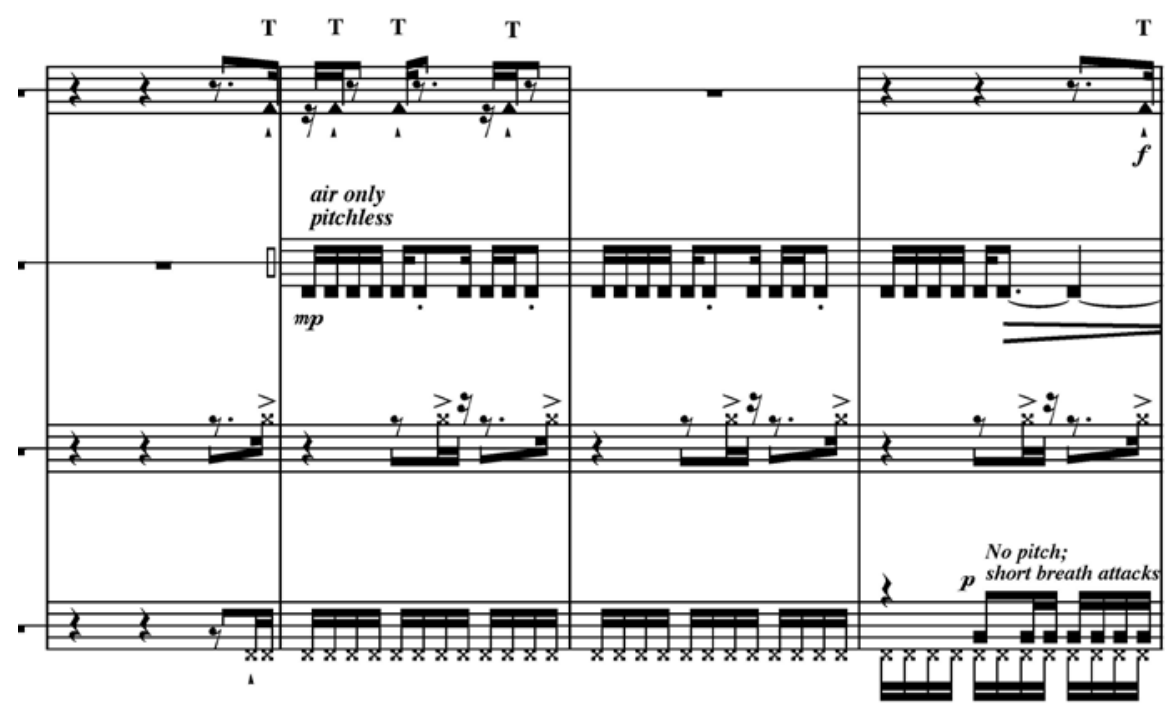

Fig. 10: Figura rítmica A6

No geral, as cordas na primeira seção da obra têm um papel mais "textural" do que rítmico e funcionam como um acompanhamento para os ostinatos que aparecem nas demais vozes. As cordas apresentam, majoritariamente, um único gesto que consiste em ataques a harmônicos artificiais em $1 / 2$ col legno battuto (com a madeira e a crina) seguidos de ricochetes. Podemos dizer que as cordas funcionam como uma espécie de ecos das figuras rítmicas presentes na primeira seção da peça, em especial ecos da figura A1. Mais uma vez, a morfologia de uma figura rítmica é transformada e utilizada em uma outra estrutura. A estratégia permite que os segmentos internos da peça sejam conectados por equivalências de vários tipos, propiciando unidade estrutural no decorrer da obra.

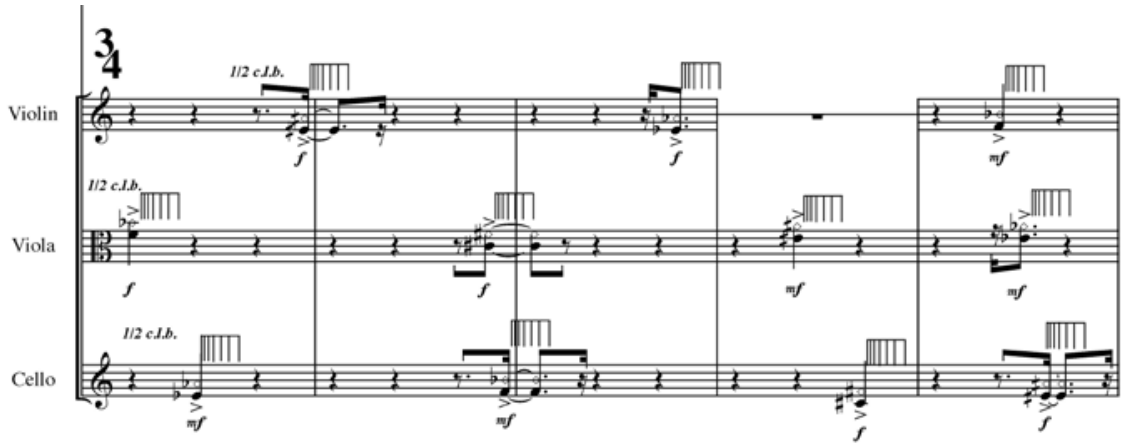

Fig. 11: Cordas usadas como ecos da figura A1.

Uma nova configuração rítmica (B1) sugere segmentos iguais, porém alongados (se tomarmos como referência o padrão regular de semicolcheias). Ainda que seja uma transformação bastante simples, i.e., o mero prolongamento das semicolcheias agora três vezes mais longo, o compositor faz uso desse material no registro grave da harpa, acrescentando aos segmentos uma ideia de direcionalidade cromática. Essa nova velocidade demarca um novo percurso estrutural na peça que coincide com a parte final da 
primeira seção. $\mathrm{O}$ "alvo" dessa trajetória, um ponto de chegada explosivo, é também o início da segunda seção da obra. B1 é uma nova camada rítmica em uma seção que já caminhava para uma espécie de conclusão. Desta forma, o compositor enfatiza o movimento cinético fornecendo mais informação sonora e mais atrito, criando uma grande força de propulsão que caminha para uma "explosão inevitável", concluindo a seção.

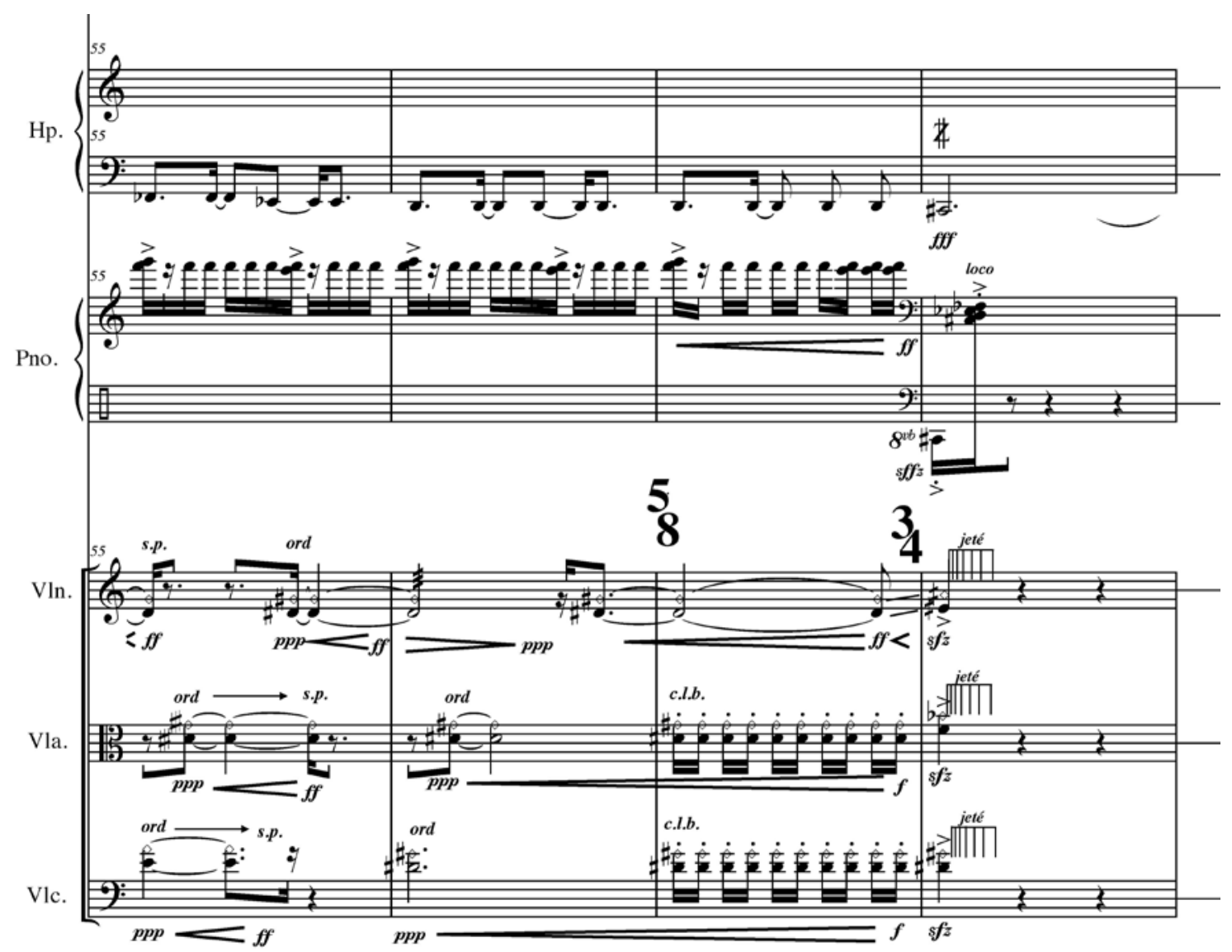

Fig. 12: Figura rítmica B1 (na harpa) e "explosão" final da seção.

A flauta apresenta uma nova figura rítmica (B2) que pode ser entendida como resultante residual do processo anterior. São pequenos ataques percussivos de pizzicatos de língua na flauta e sem altura definida. É uma figura de grande importância estrutural na obra, mas que mantém características de modelos rítmicos já utilizados, como o envelope decrescente e o som percussivo dos instrumentos de sopro). A despeito de algumas características já presentes em outras figuras, temos aqui um novo modelo, dessa vez oriundo da peça Surfboard, de Tom Jobim.

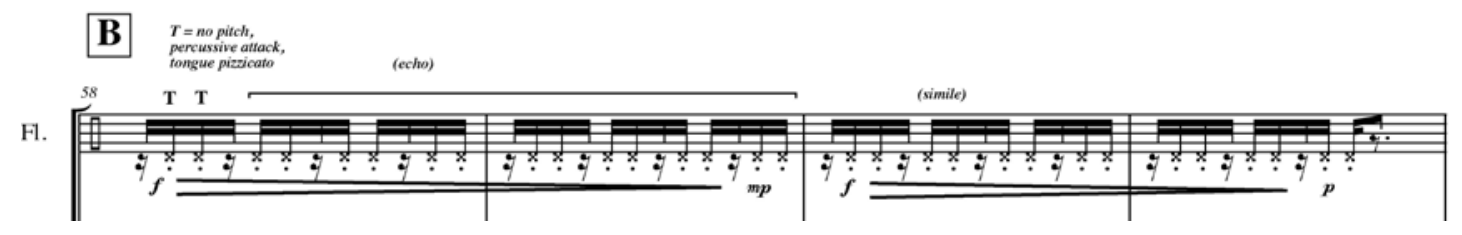

Fig. 13: Figura rítmica B2. 
O compositor procura extrair vários componentes sonoros e estruturais de B2. A ideia de "eco" e, consequentemente, de distância e espacialização é inerente à figura e será utilizada através de várias configurações instrumentais. Eventualmente, essa figura conterá notas fixas com funções tanto de acompanhamento como elemento melódico.

A figura rítmica C1 (Fig. 14), introduzida pelos brake drums, é bastante similar ao contínuo métrico que denominamos anteriormente como a. A diferença está nas acentuações, o que the confere uma estrutura característica de figura rítmica. O envelope dinâmico (crescendo/decrescendo) funciona como um operador que esculpe toda a orquestração do trecho. Podemos inferir, portanto, que a, executado pelas madeiras e metais, é submetido a uma mutação que o transforma na figura rítmica C1. Novamente o compositor esculpe o material sonoro a partir de transformações bastante sutis, seja através de operadores métricos (acentos, pausas), timbrísticos (uso de técnicas estendidas e expansão do ensemble), ou ainda envelopes dinâmicos. Na Fig. 14, notamos ainda uma sutil transformação de velocidade no material do piano durante três compassos. Enquanto isso, as cordas ecoam o gesto inicial da harpa, agora criando um movimento mais complexo e irregular. A sobreposição de materiais aliada a um movimento direcional do material sonoro - este último enfatizado pelas figuras rítmicas e pelo envelope dinâmico - implica o aumento do grau de complexidade do trecho e resulta no desfecho da seção. Nota-se aqui a mesma estratégia formal aplicada no trecho da Fig. 12 acima: adensamento e clímax. 


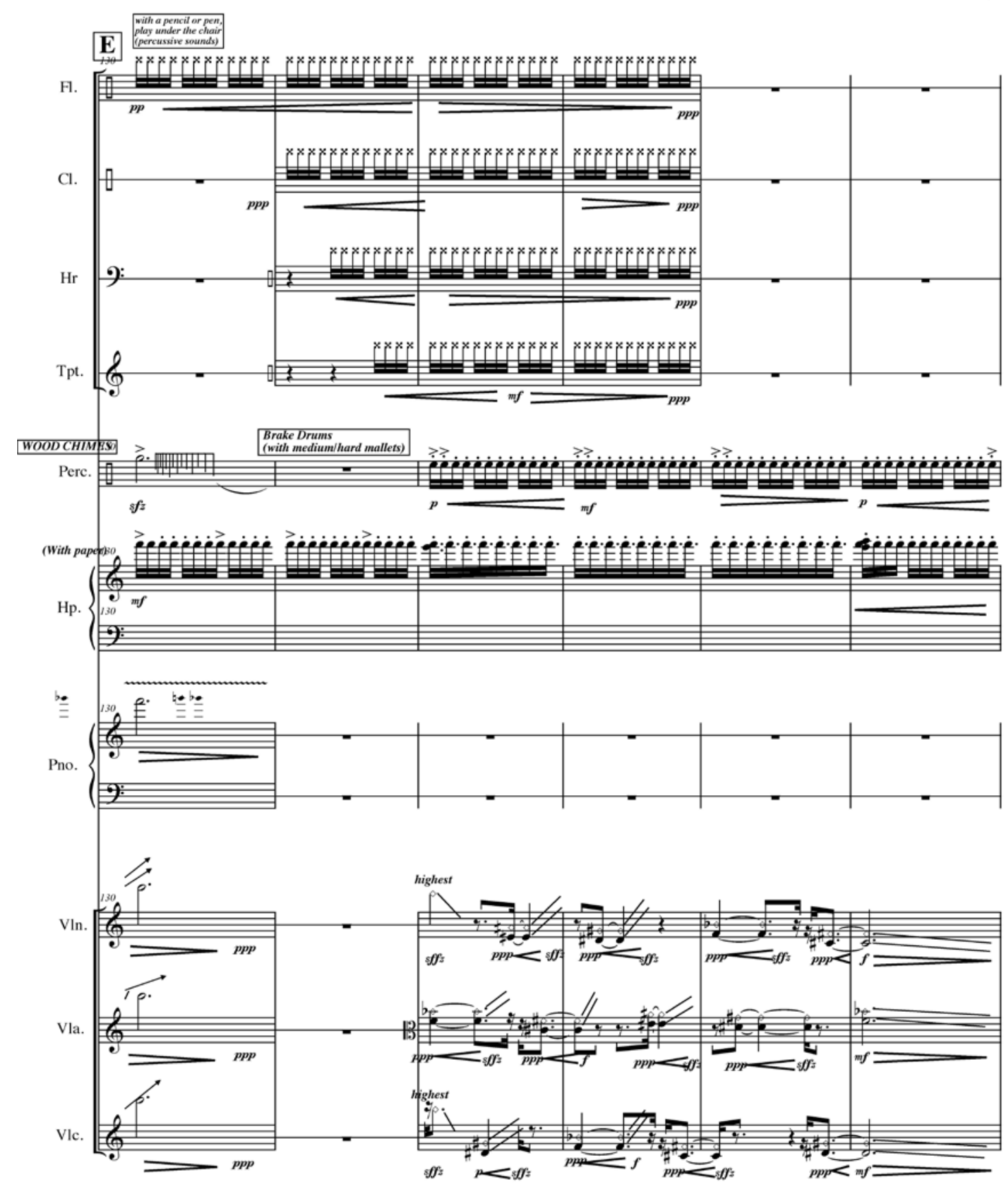

Fig. 14: Figura rítmica C1.

Na sequência, as cordas retomam a figura B2 oriunda de Surfboard, cujo grau de maleabilidade é ainda mais explorado. Há uma intensa justaposição de técnicas criando vários níveis de agrupamentos sonoros. Como já observamos, estes agrupamentos são "costurados" dentro de um mecanismo que envolve timbre, ritmo e direcionalidade. O compositor trabalha cada um desses elementos ora de forma simultânea - onde as transformações ocorrem conjuntamente e onde um parâmetro necessariamente interfere em outro -, ora isoladamente. Essa variabilidade das combinações dos materiais é desenvolvida livremente pelo compositor. Isso permite um grande número de possibilidades e, consequentemente, um caráter imprevisível no decorrer da obra. Em geral, ob- 
serva-se uma estratégia baseada em itinerários de construção e extinção das estruturas internas da obra.

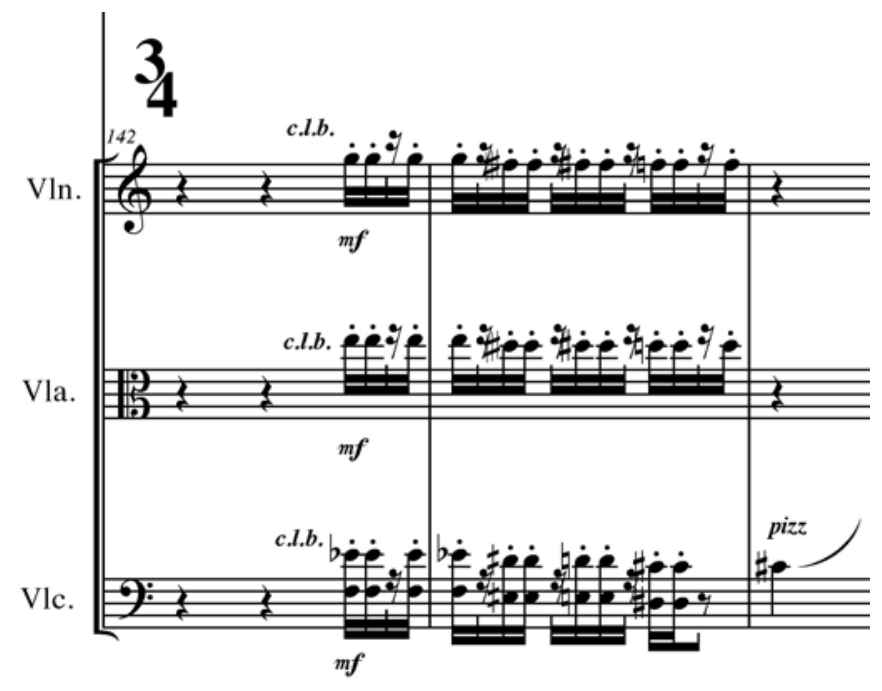

Fig. 15: Figura rítmica B2 (agora apresentada em blocos pelas cordas).

A figura rítmica D1 (Fig. 16), apresentada pela harpa no compasso 167, é uma variação de A1. Dentro de um sistema onde as figuras rítmicas são fundamentais na construção da peça, pequenas transformações dessas figuras, aliadas a variáveis timbrísticas e harmônicas, geram novos materiais potencialmente bem mais complexos. A figura D1, dentro desse sistema de transformações, aparece "expandida" com sons bastante graves e separados uns dos outros na própria harpa (notas C\#, na região grave). Desta forma, verificamos que as múltiplas velocidades, cada uma em registros distintos, revelam a complexidade de um sistema de matrizes simples, mas que geram material bastante complexo e em constante mutação.

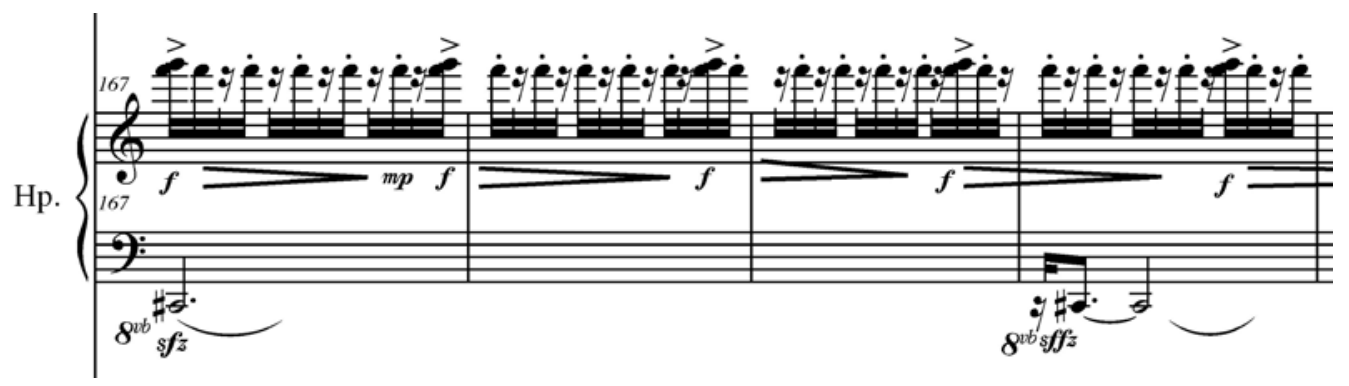

Fig. 16: Figura rítmica D1, uma variação de A1.

Os dois exemplos a seguir atestam a complexidade do sistema envolvendo a figura D1. Notamos não apenas a sobreposição de várias figuras rítmicas já descritas anteriormente, mas também um conjunto de gestos e uma diversidade de timbres que resultam num sistema bastante dinâmico. 


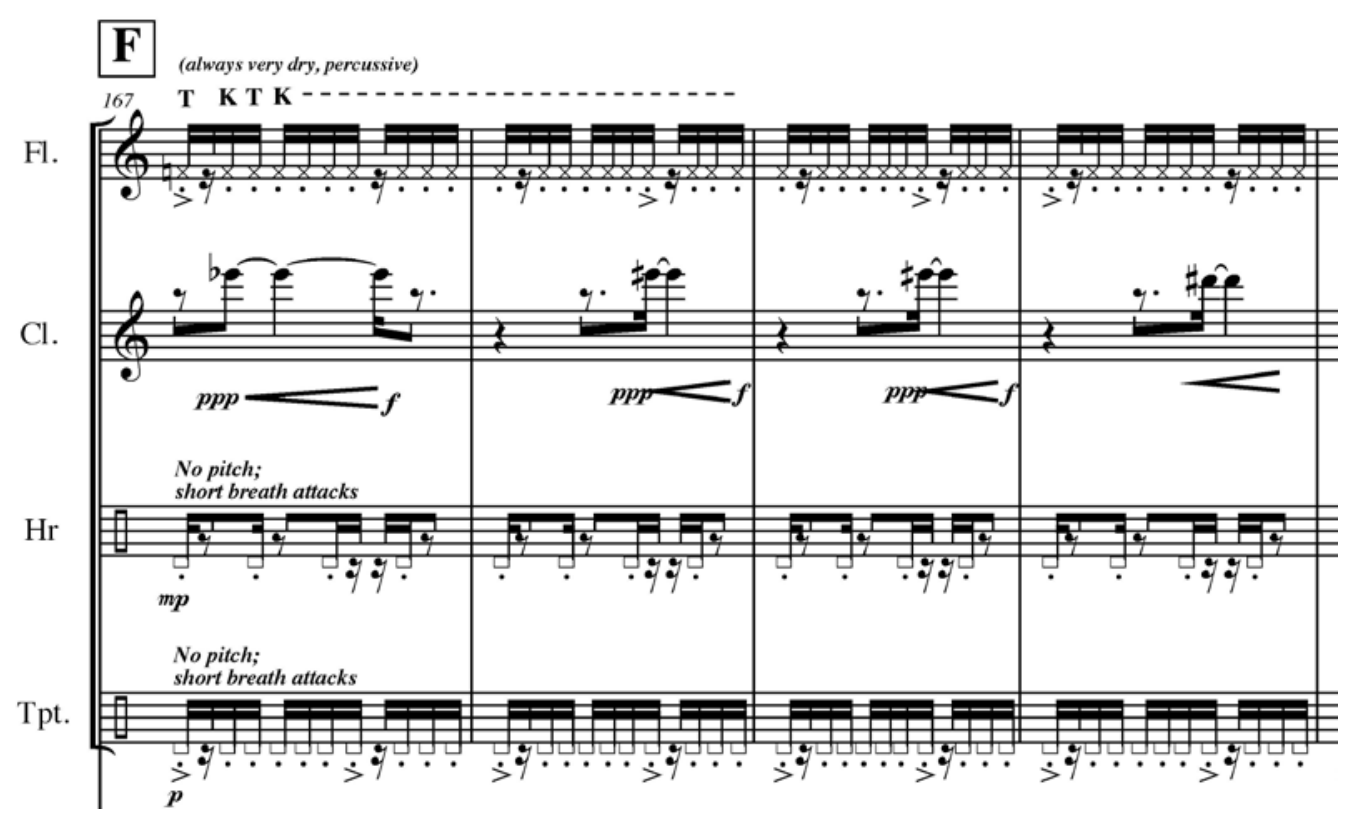

Fig. 17: Três camadas acima da figura D1 (Fig. 15).

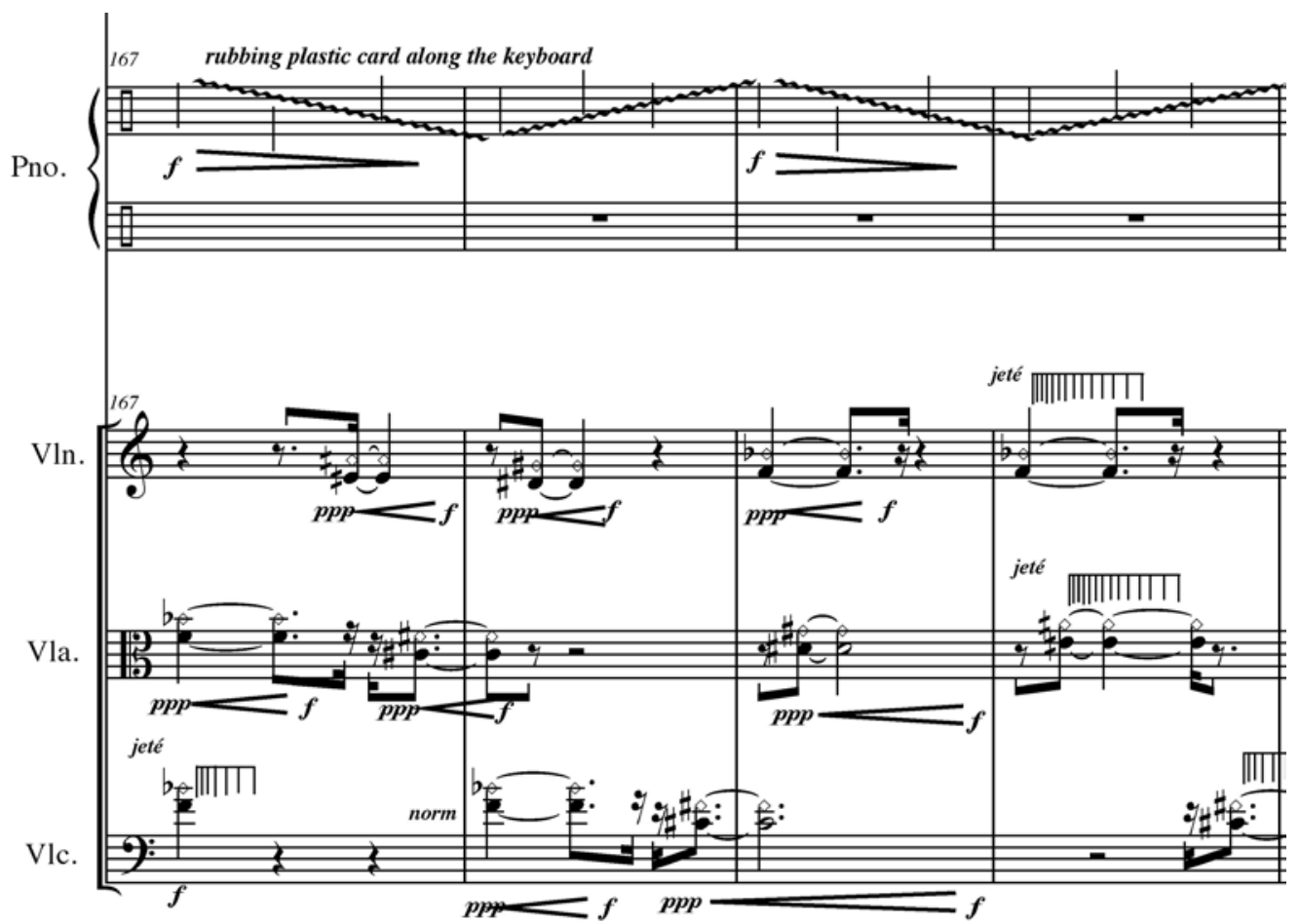

Fig. 18: Duas camadas abaixo da figura D1 (Fig. 15).

O contínuo métrico $\beta$ é exposto pela primeira vez no meio de uma textura bastante densa. Enquanto as cordas reexpõem a textura do início da música, o contínuo métrico manifesta-se de forma velada e secundária. No entanto, rapidamente $\beta$ assume uma posição de destaque, com um aumento gradual de sua presença neste trecho: inicia-se com a marimba, expande-se pelas madeiras e metais, e finalmente todo o ensemble articula um único contínuo métrico. Completados aproximadamente $3 / 4$ da peça, pela 
primeira vez notamos a presença de um único elemento musical e a ausência de sobreposições. Em parte, o esvaziamento dos materiais permite que a obra respire e caminhe para uma seção final de grande complexidade. As três figuras a seguir (19, 20 e 21) mostram o contínuo métrico $\beta$ partindo de uma única célula timbrística (marimba) e chegando ao tutti instrumental.

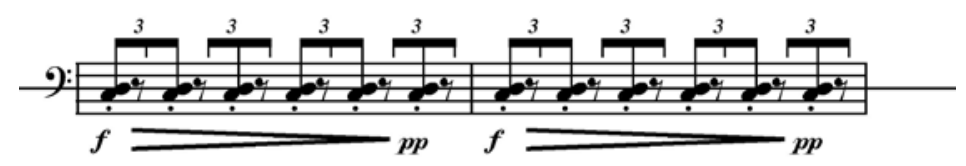

Fig. 19: Contínuo métrico $\beta$.

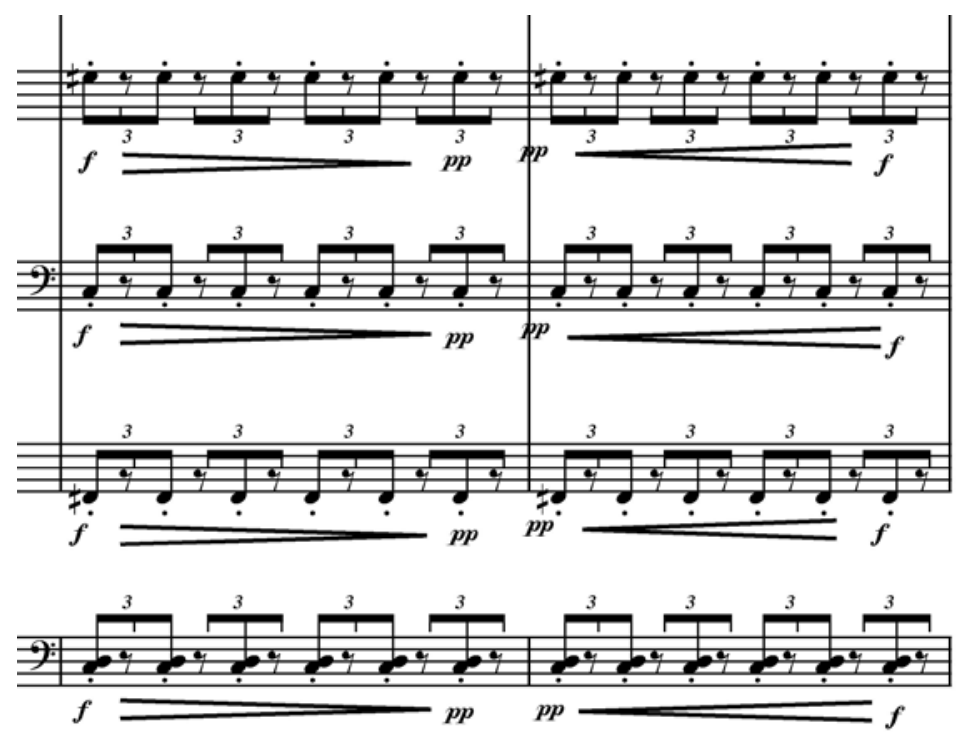

Fig. 20: Contínuo métrico $\beta$ verticalizado (uma forma de variação utilizada).

Na figura a seguir temos a continuação do desenvolvimento de $\beta$ : ele não só aparece verticalizado, como também está sobreposto ao contínuo métrico a e à figura rítmica $\mathrm{A} 1$. 


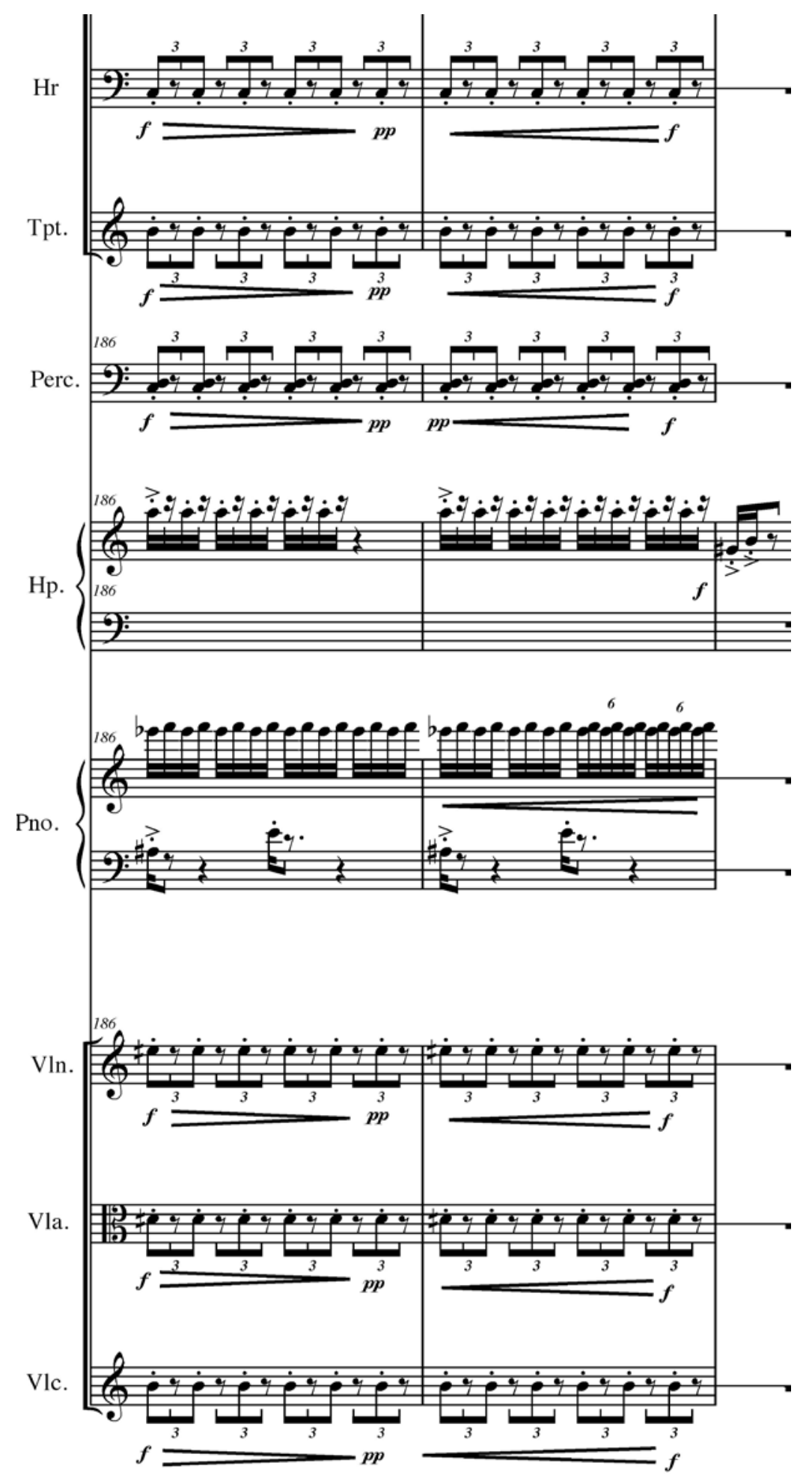

Fig. 21: Contínuo métrico $\beta$ expandido verticalmente.

A última figura rítmica de Areia II (E1) e sua imediata transformação (E2) diferenciam-se das demais figuras por conta das acentuações deslocadas e pelo seu uso bastante maleável no trecho final da peça. Ou seja, E1 é uma figura que será pulverizada em diversos timbres e no deslocamento de seus acentos, alterando a sua morfologia inicial. 
Vale ressaltar que a maleabilidade da figura está em sincronia com o tratamento dado pelo compositor ao longo de toda a peça. O que se observa é que existem trechos onde as figuras rítmicas são mais rígidas - fixas no eixo temporal -, enquanto em outros trechos o grau de variabilidade é maior. Esses diferentes graus de manipulação das figuras estão vinculados à estrutura interna da peça e ao próprio comportamento temporal, melódico, harmônico e expressivo da obra. Como abordado anteriormente, nota-se que o condutor principal desses graus de manipulação é a função que a figura assume em um determinado trecho: ora a figura é o foco da informação musical, ora ela passa a ser elemento secundário, que, mesmo sendo um importante operador na ampliação de cores e variabilidade do material, aparece diluída no texto musical.

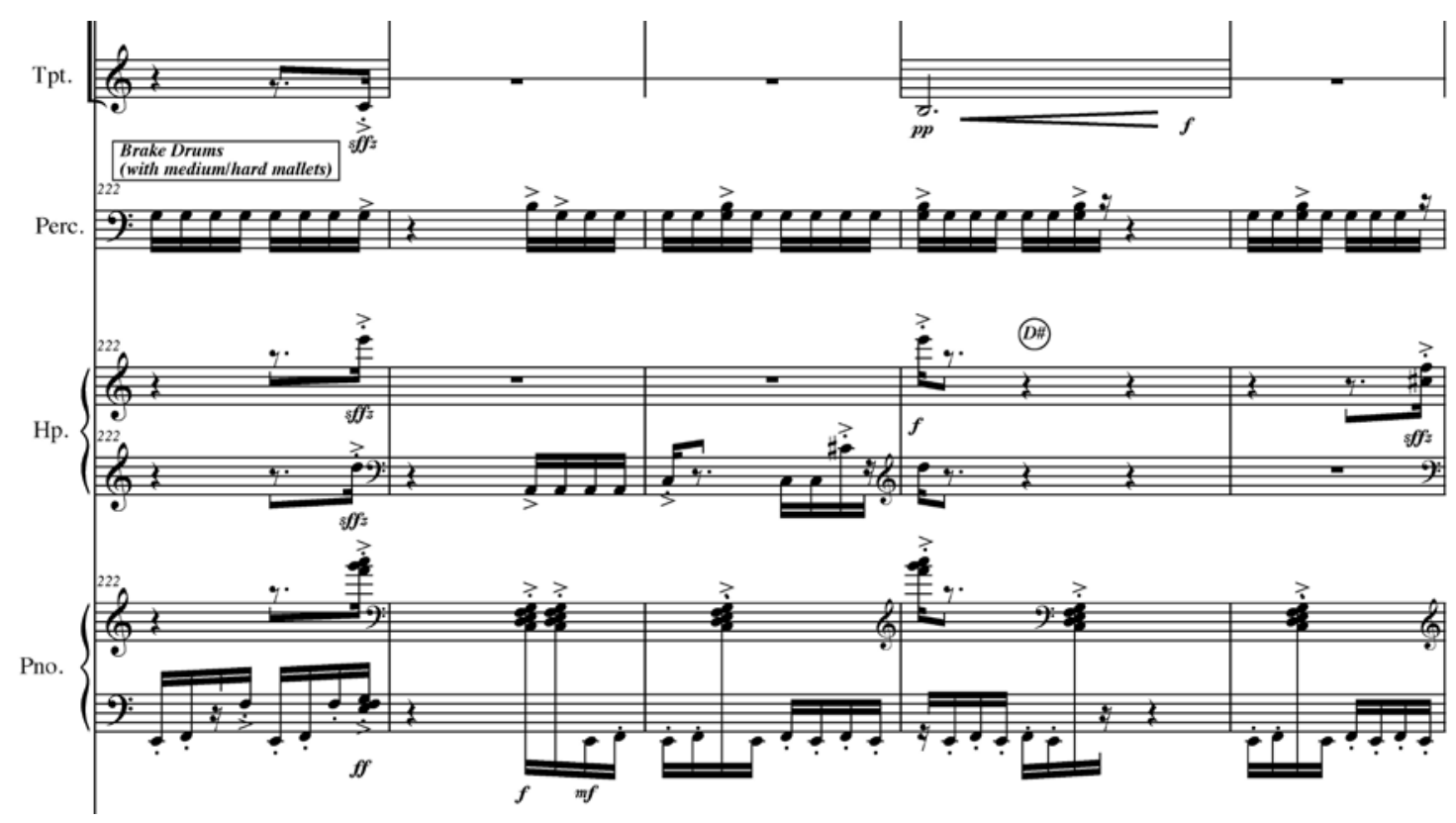

Fig. 22: Figura rítmica E1.

\section{Distribuição das figuras rítmicas em Areia II}

Os quadros a seguir (Quadros 3a, 3b, 3c, 3d e 3e) mostram a distribuição das figuras rítmicas em cada compasso na obra. Em azul temos as figuras propriamente ditas. Em vermelho temos a indicação do material rítmico guia, podendo ser uma figura ou um contínuo métrico. É um elemento que atua como padrão de base e que fornece estabilidade sobre o qual outros materiais serão dispostos.

Através do mapeamento realizado, não observamos a existência de uma formalização da distribuição da densidade de figuras rítmicas ao longo da peça. No entanto, observamos graus de adensamento seguidos de esvaziamentos das figuras (e vice-versa). É uma estratégia usada pelo compositor em várias seções. Isso confirma a existência de uma construção de trajetórias dos materiais, como foi examinada anteriormente durante a análise de algumas figuras rítmicas. Como exemplo, tomemos os primeiros compassos da peça: após uma introdução relativamente estável com apenas uma figu- 
ra-guia presente, nota-se um rápido adensamento de figuras que culminam na ausência de qualquer elemento rítmico, sejam figuras, sejam resíduos de contínuos métricos. Essa trajetória direcional de todo o período passa pelo esgotamento do material. Já a partir do compasso 27 (Quadro 3a), um longo percurso relativamente uniforme percorre várias seções da peça sem que ocorram articulações formais: é um trecho de desenvolvimento bastante livre do material. Ao evitar a repetição de estratégias de articulação entre as seções, o compositor busca evitar a previsibilidade de soluções formais.

Outro trecho que corrobora a ideia de direcionalidade ocorre entre os compassos 142 e 193 (Quadros 3b e 3c): entre os compassos 142 e 188 - um trecho relativamente longo - temos um material de densidade estável, essencialmente com duas figuras rítmicas sobrepostas. Já entre os compassos 189 e 193 temos um adensamento de até cinco figuras sobrepostas compactadas em um espaço de tempo bastante curto, o que evidencia um momento de maior complexidade rítmica entre o final de uma seção e o início de outra. Aqui, sim, temos novamente uma seção organizada sobretudo pela direcionalidade de seus elementos constitutivos.

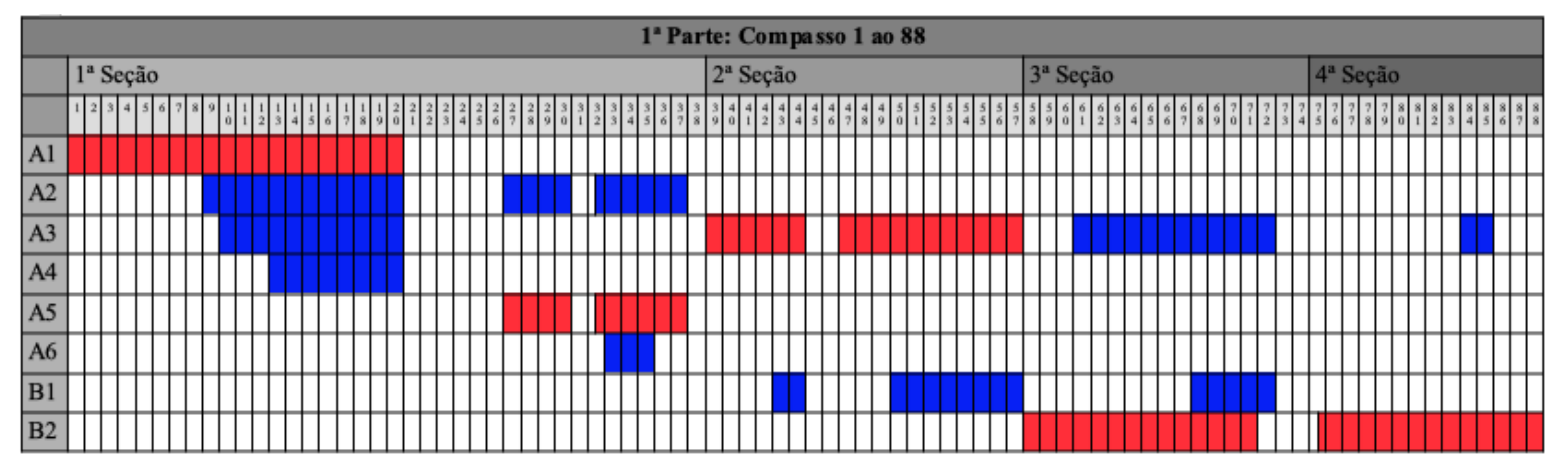

Quadro 3a: Figuras rítmicas entre os compassos 1 e 88.

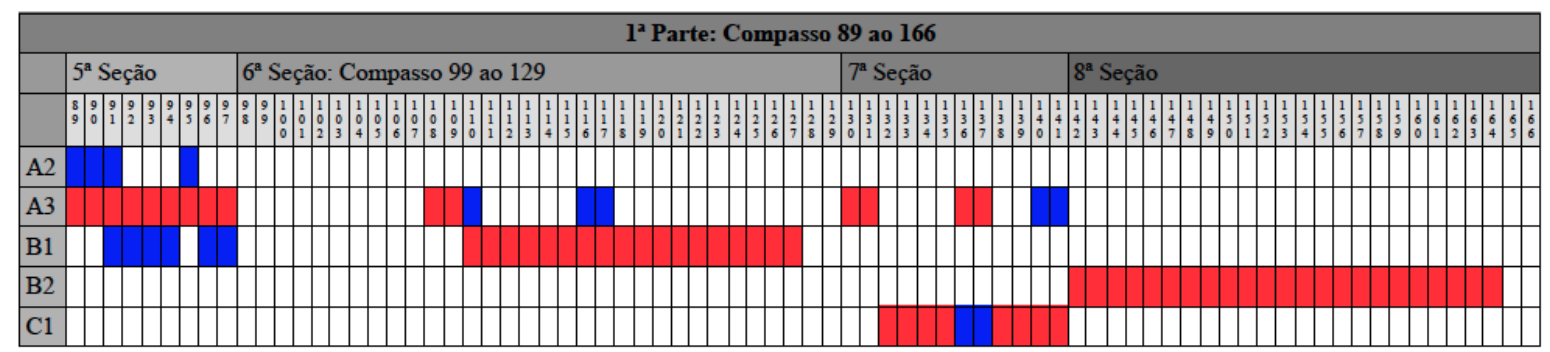

Quadro 3b: Figuras rítmicas entre os compassos 89 e 166.

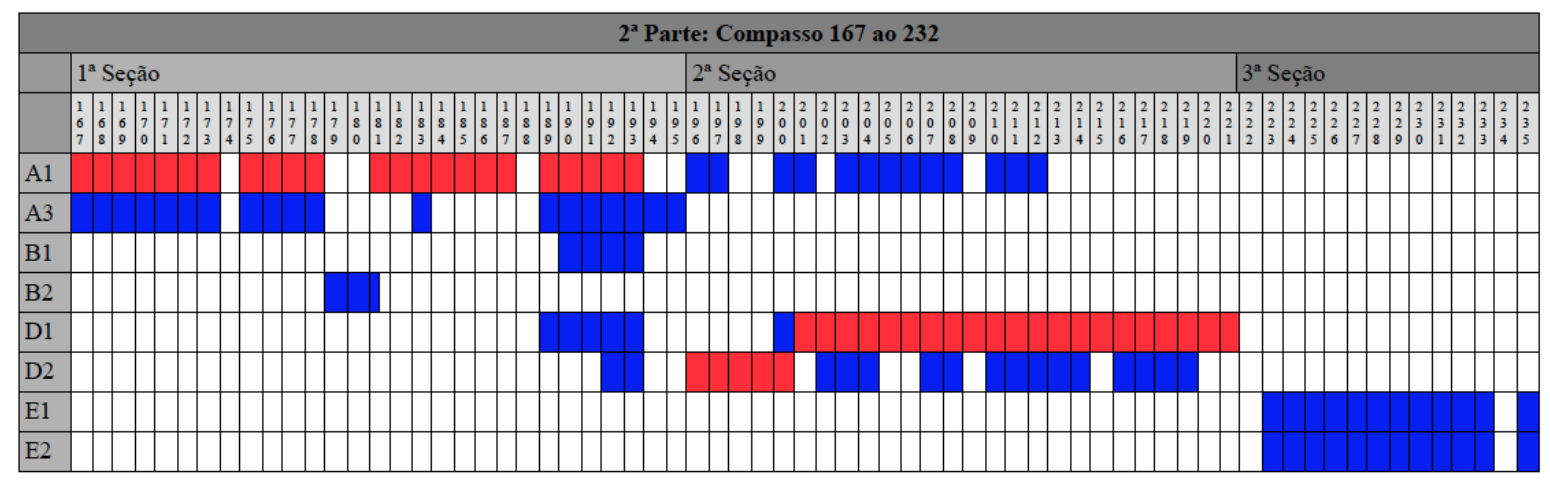

Quadro 3c: Figuras rítmicas entre os compassos 167 e 235. 


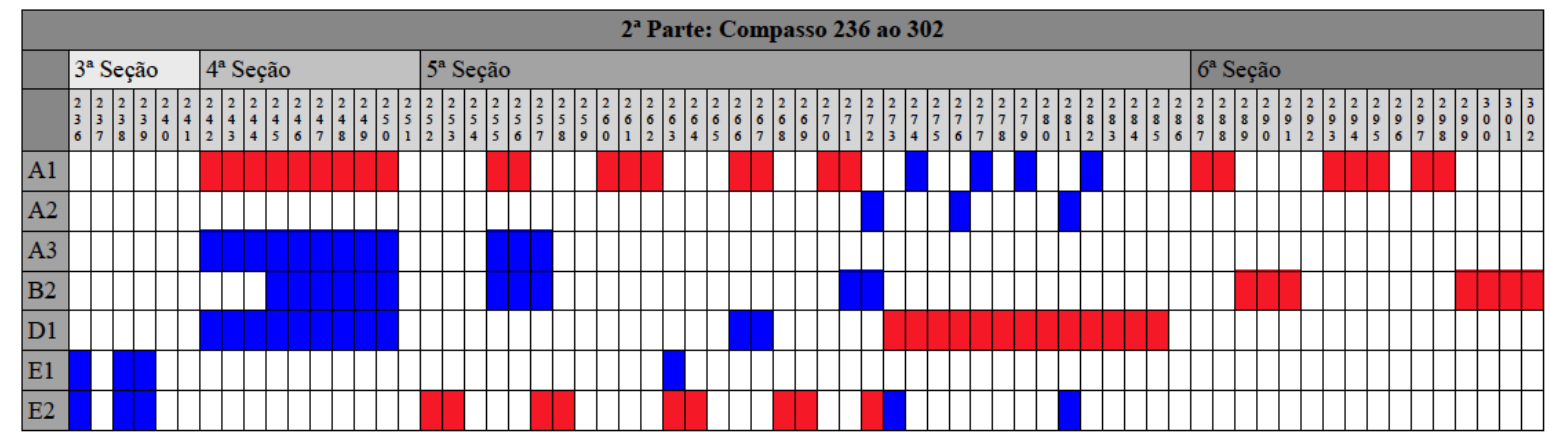

Quadro 3d: Figuras rítmicas entre os compassos 236 e 382.

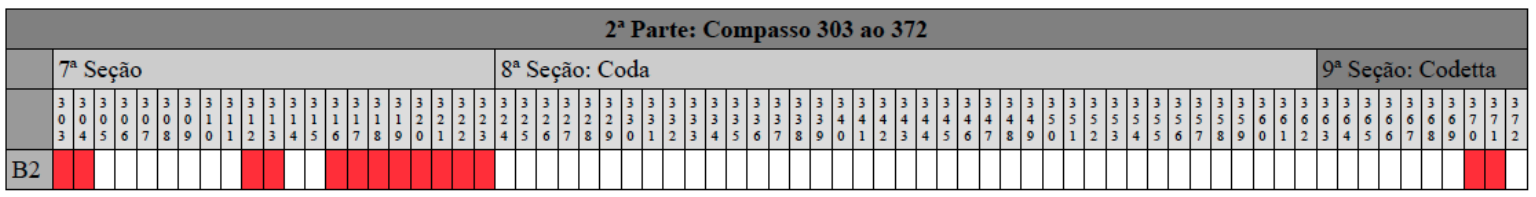

Quadro 3e: Figuras rítmicas do compasso 383 ao fim.

Com exceção de algumas poucas lacunas e da parte final da obra, a partir dos quadros acima nota-se a presença quase constante de pelo menos um elemento rítmico presente em cada trecho da obra. Este encadeamento de figuras rítmicas funciona como espinha dorsal da organização formal de Areia II. Sobre esse encadeamento serão dispostas outras camadas com elementos timbrísticos, melódicos e harmônicos. É o sistema de relações que, num processo de sinergia, esculpe o material sonoro.

\section{Simha Arom e Areia II}

Em Areia II, o elemento estrutural de maior importância é, sem dúvida, o ostinato. Laure Schnapper, no Grove Music Online, define ostinato como "Um termo usado para referir-se à repetição de um padrão musical muitas vezes seguidas, enquanto outros elementos musicais estão, geralmente, mudando" (2013, "Ostinato", tradução nossa). Diferentemente dos motetos renascentistas e do basso ostinato barroco, onde os ostinatos serviam de suporte para o contraponto que ocorria nas outras vozes, em Areia II são os próprios ostinatos que geram o movimento e o contraponto na música. Quando apresentados de forma simultânea, os ostinatos criam um contraponto entre eles, gerado de três maneiras diferentes: por ostinatos decorrentes de uma mesma figura, que são deslocados no tempo um em razão do outro, por ostinatos resultantes de diferentes figuras sobrepostos um ao outro, ou até mesmo por uma mistura dessas duas possibilidades. Essa sobreposição de ostinatos é também uma das características da música centro-africana. Sobre isso, Rose Brandel faz a seguinte afirmação para o Harvard Dictionary of Music no artigo sobre África:

O ostinato africano, normalmente muito curto e com pouca variedade de alturas, pode ser contínuo ou intermitente, vocal ou instrumental, e pode aparecer acima ou abaixo da linha principal. Frequentemente existe um multiostinato, dois ou mais ostinatos movendo-se em contraponto, com ou sem uma linha melódica maior. (BRANDEL, 1969, p.20, tradução nossa). 
Além dos tipos descritos acima, os ostinatos em Areia I/ sofrem diversas formas de variações ao longo do discurso musical: aumentação (expansão) ou diminuição (corte) de um padrão rítmico, transformações melódicas, interrupção abrupta de um padrão rítmico, inserção de um "elemento externo" entre os ostinatos, ou ainda o "transitar" de um ostinato entre diferentes cores instrumentais. Esta forma de estruturação da música através de ostinatos e suas variações múltiplas é típica da música tradicional centro-africana. Segundo Arom, "Se alguém tivesse que descrever em uma fórmula todos os procedimentos polifônicos e polirrítmicos utilizados na República Centro Africana, poder-se-ia defini-los como ostinatos com variações" (1991, p.39-40, tradução nossa). Ou ainda, em outro momento, "Um curto tema em ostinato, simples, porém variado - esta poderia muito bem ser uma descrição do contraponto vocal dos pigmeus" (1991, p.42, tradução nossa). Achamos aqui o principal ponto de conexão entre Areia I/ e as manifestações musicais dos pigmeus aka. Assim como na descrição do contraponto centro-africano feita por Arom, Areia II também apresenta figuras rítmicas curtas, geralmente do tamanho de um compasso, que se repetem por um determinado período. No entanto, os períodos em Areia II não se comportam de maneira estritamente regular, como aqueles encontrados na cultura musical dos povos centro-africanos. Sendo assim, todo o desenvolver dos ostinatos de uma determinada figura rítmica dentro de cada seção de Areia II pode ser compreendido como um período. O compositor preocupa-se mais com as operações feitas nos elementos internos de cada ostinato (mesmo que em um grau microscópico) do que em preservar estruturas simétricas características de uma música baseada em ostinatos. São essas operações que garantirão a evolução da obra e a ideia de uma trajetória que, apesar de contínua, se mostra imprevisível.

Um exemplo desta imprevisibilidade consiste no uso de cesuras em determinados pontos-chave da obra. Nota-se que, ao longo de toda a composição, são feitas somente três alterações de andamento, todas em momentos de mudança abrupta, indicando uma cesura no discurso musical. A primeira ocorre na metade da obra, onde um ritardando e uma pausa geral que precede um tutti separam as duas partes da música. Verificase, portanto, que uma breve diminuição da velocidade articulou uma importante segmentação do discurso musical na forma de justaposição. A segunda mudança ocorre na parte final da obra e é essencialmente um ajuste temporal para permitir que gestos virtuosísticos sejam efetivamente executados pelos instrumentistas. Pode-se dizer, nesse caso, que a mudança de velocidade tem um caráter pragmático, sem relação com o desenvolvimento temporal ligado às figuras rítmicas. Finalmente, a última alteração de andamento acontece somente três compassos antes do final da peça. É um momento de extinção do material. Os ciclos rítmicos construídos e modelados dentro da obra, bem como o desenvolvimento de camadas, texturas e variações, chegam a um ponto de esgotamento. A mudança de andamento acontece como evidência de um encerramento.

[...] nunca há, dentro de uma peça musical, a menor variação no andamento, que se mantém constante até o fim, sem accelerando, ritardando, rubato ou fermata. Se, por razões rituais particulares, há peças musicais sucessivas com diferentes tempos (durante uma cerimonia por exemplo), os músicos centro-africanos nunca criam uma transição de uma peça para outra; eles as justapõem, preservando uma ruptura entre as duas. 
Portanto, concluímos que a preservação do andamento durante a maior parte da obra, e principalmente o uso da justaposição e ruptura na mudança de uma seção para outra, também configuram-se como elementos de conexão entre a estruturação musical de Areia Il e a música do povo aka.

Uma reflexão a respeito deste procedimento formal de ruptura e justaposição passa pela negação de uma estética bastante preocupada com o continuum sonoro. Trata-se aqui de uma reflexão pessoal do compositor a respeito do espectralismo, uma influência bastante importante para Lunsqui. O emprego de justaposições e cortes formais abruptos, mesmo que utilizados por um compositor como Olivier Messiaen (um dos responsáveis pela expansão do uso da harmonia-timbre na música do século XX), é normalmente rejeitado pela estética espectralista. Citamos Messiaen por ter sido ele professor de Tristan Murail, um dos pioneiros da chamada música espectral. Murail era professor de Lunsqui na época da composição de Areia II. A obra foi, portanto, uma oportunidade de rompimento com alguns dos preceitos oriundos do pensamento espectral, especialmente no campo rítmico e formal.

\section{Considerações finais}

Neste artigo, analisamos as características estruturais encontradas em Areia II e suas relações com modelos de organização temporal e rítmica oriundos de três obras de origens bastante distintas: a canção Yangissa, da tribo centro-africana Aka, a peça Surfboard, de Tom Jobim, e a obra inacabada Três peças para Orquestra de Câmara, de Arnold Schoenberg. A combinação de uma série de ostinatos, gestos melódicos e agrupamentos timbrísticos criados a partir de materiais aparentemente desconectados resultou em uma obra com percurso imprevisível, porém orgânico. É exatamente o fator rítmico que terá um papel estrutural unificador fundamental em toda a obra. Através dos pulsos oriundos dos aka, bem como da métrica peculiar de Surfboard, o compositor navega em várias direções mantendo um padrão de movimento relativamente constante. Essa homogeneização que o elemento rítmico imprime à obra, e que na visão de Theodor Adorno afastaria a mesma de uma experiência exclusiva, colocando-a numa espécie de template estético, é justamente a estratégia usada por Lunsqui na composição de Areia II. O desafio, neste caso, é criar uma obra que tenha unidade e que não se enquadre em nenhum dos modelos utilizados como fonte sonora. As três matrizes estéticas presentes no material de base de Areia II (Yangissa, Surfboard e Três peças para Orquestra de Câmara) são partes de um processo de sinergia que busca ultrapassar categorizações estilísticas. A inclusão estética das culturas examinadas em Areia I/ tem como resultante uma obra que não se resume a um experimento de colagens de materiais.

Vimos que a estruturação do discurso musical baseada em ostinatos é típica da música tradicional da África Central praticada pelo povo aka. Esta característica configura-se na principal semelhança entre a articulação rítmica de Areia /l e a música tradicional centro-africana. Em Areia II, a justaposição de planos sonoros e a sobreposição de figuras rítmicas são os principais procedimentos composicionais utilizados para estruturar e desenvolver o discurso musical. 
Areia II apresenta uma estrutura bipartite, sendo que as duas últimas seções da segunda parte apresentam um comportamento diferente de todas as outras. Entendemos que o compositor trabalha uma diversidade de materiais bastante grande no delineamento formal da obra e que o uso das figuras rítmicas não compromete o grau de imprevisibilidade almejado pelo compositor. O material das últimas seções, por exemplo, é desenvolvido e explorado não somente a partir de padrões rítmicos, mas também a partir de perfis melódicos que fornecem material de grande plasticidade. $O$ foco na seção final não é a negação da primazia do plano rítmico que caracteriza a maior parte da obra, mas, sim, a sua própria extinção e esgotamento. Esse tipo de operação é bastante importante para o compositor. Metaforicamente, a mistura de ingredientes que operam como reagentes dentro de um processo físico-químico possui uma macroestrutura pragmática: existe uma sequência de ações principais imutável, constituída pela manipulação dos elementos, suas interações e as resultantes, ou seja, o produto da operação. No entanto, eventos internos presentes durante o processo podem assumir graus de complexidade que vão muito além do pragmatismo da operação em si. É neste território de complexidades internas que Lunsqui procura dialogar com as matrizes sonoras conhecidas utilizadas em Areia II. Em nosso artigo, privilegiamos apontar as estruturas rítmicas usadas na obra, além de seus encadeamentos no eixo do tempo. Pontuamos ainda algumas operações envolvendo timbres, agregados harmônicos e estratégias formais, como a cesura e a justaposição, ambas resultantes de uma direcionalidade quase onipresente na obra.

A ruptura de modelos estéticos estabelecidos, bem como o interesse por modelos sonoros de diferentes matrizes culturais, tem sido um dos muitos caminhos percorridos por compositores da chamada música contemporânea. No caso de Lunsqui, onde o jazz e a música brasileira foram fundamentais em sua formação musical, duas referências contemporâneas criam um elo direto no que consideramos ser uma atitude de inclusão de estéticas: são eles os compositores Steve Reich e György Ligeti. Não se trata de compartimentalizar um grupo de compositores cuja lista seria muito mais ampla do que os nomes citados neste trabalho e em constante evolução. Trata-se de verificar uma conexão criada a partir de formas de observar, absorver e experimentar com múltiplas culturas na criação musical. Reich pesquisou a música africana em primeira mão através de seus estudos de percussão em Gana. A obra Drumming (1970-1971), um marco do minimalismo, é resultado desses estudos. Ligeti foi influenciado pelo jazz e pela música do povo aka numa fase de sua carreira onde ele já havia criado algumas de suas obras mais conhecidas, como Lux Aeterna (1966), Lontano (1967) e o Concerto de Câmara para 13 instrumentos (1969-1970). A partir das influências oriundas dos aka, do jazz e de Nancarrow, Ligeti compõe o Concerto para Piano (1985-1988), o Concerto para Violino (1989-1993), além de alguns dos Estudos para Piano (1985-2001). As obras dos dois compositores são exemplos da fusão de estéticas que fluem dentro de trabalhos absolutamente originais.

As influências musicais utilizadas por Lunsqui na composição de Areia I/ podem ser observadas tanto no nível microestrutural quanto no nível macroestrutural. No ní- 
vel microestrutural, Lunsqui extraiu figuras rítmicas e perfis melódicos provenientes da canção aka Yangissa, da música Surfboard, de Tom Jobim, e do movimento Gehende Viertel, das Três peças para Orquestra de Câmara, de Schoenberg, transformando-os em agrupamentos de ostinatos, gestos melódicos e agregados harmônicos em Areia II. No nível macroestrutural, as relações com as obras já citadas podem ser encontradas nas seguintes situações: a) uso de camadas independentes: ocorre, por exemplo, quando blocos texturais encontrados nas cordas contrapõem-se às figuras rítmicas executadas pelos demais instrumentos. As Fig. 17 e 18 ilustram este tipo de construção. O procedimento gera a sobreposição de dois planos sonoros diferentes, aproximando Areia II da referência com os dois tempi paralelos observados pelo compositor em Surfboard; b) justaposição entre as seções: separadas por cesuras, a justaposição das seções aproxima Areia II tanto da música centro-africana como das Três peças para Orquestra de Câmara, de Schoenberg.

A direcionalidade característica de Areia II, ou seja, o pensamento de construção de percursos sonoros fluídos e com itinerários bastante definidos, é fundamental na macroestrutura de Areia II. De certa forma, ao estabelecer a direcionalidade como uma espécie de "regra" dentro do sistema, o compositor terá autonomia no uso dos materiais dentro de cada seção da peça. A justaposição, por sua vez, passa a ser uma ocorrência "natural" na medida em que cada seção é "resolvida" dentro da direcionalidade estabelecida. O risco desta estratégia é ter uma obra constituída por retalhos formais. Cabe ao compositor, portanto, criar sólidas relações e conexões internas tanto no nível microscópico quanto na macroestrutura. São relações que devem garantir a particularidade do instante dentro da obra, bem como a sua organicidade totalizante.

Areia II é resultado de um amálgama de materiais de origens distintas. $O$ desafio do compositor foi esculpir estes elementos criando uma sinergia estética, onde as características morfológicas e culturais de cada material são transmutadas e reveladas dentro de um novo universo de sons e impressões.

\section{Referências}

ABRAHAM, A. Moles. Informatique du rhythme. No "Les rythmes". Conferências apresentadas no Colóquio sobre os ritmos em Lyon em dezembro 1967, suplemento $\mathrm{n}$. 7 do Journal française d'oto-rhino-laryngologie. Lyon: Editions Simep, 1968.

ADORNO, Theodor W. A Filosofia da Nova Música. São Paulo: Perspectiva, 1974.

AROM, Simha. Aka Pygmy Music. Berlin, Venezia: Philips, 1973.

AROM, Simha. Time structure in the music of Central Africa: periodicity, meter, rhythm and polyrhythmics. Leonardo, v. 22, n. 1, p. 91-99, 1989. Disponível em: http://www. jstor.org/stable/1575146. Acesso em: 2 fev. 2014. 
AROM, Simha. African polyphony and polyrhythm: musical structure and methodology. Trad. Martin Thom, Barbara Tuckett e Raymond Boyd. Cambridge: Cambridge University, 1991.

AROM, Simha et al. La Categorisation des Patrimoines Musicaux dans le Sociétés de Tradition Orale. Categories et Categorisation. Une Perspectives Interdisciplinaire. Paris: Peeters, 2008.

AROM, Simha; SCHOMANN, Stefan. African Rhythms: Pierre-Laurent Aimard/Aka Pygmies, Dancers of the Gods. Warner Classics, 2003. 1 CD.

BAHUCHET, Serge. Les Pygmées Aka de la forêt Centrafricaine. Se nourrir en forêt équatoriale: Anthropologie alimentaire des populations des régions forestières humides d'Afrique. Paris: Unesco, 1989. p. 19-25.

BAHUCHET, Serge. L'invention des Pygmées. Cahiers d'études africaines, Paris, v. 33 n. 129, p. 153-181, 1993.

BAHUCHET, Serge. De la musique considérée comme une philosophie (chez les Pygmées Aka de Centrafrique). In: DEHOUX, V.; FÜRNISS, S.; LE BOMIN, S.; OLIVIER, E.; RIVIĖRE, H.; VOISIN, F. Ndroje balendro: musiques, terrains et disciplines. Textes offerts à Simha Arom. Paris: Peeters, 1995. p. 57-65.

BRANDEL, Rose. África. In: APEL, Willi. Harvard Dictionary of Music. 2. ed. Cambridge: Harvard University Press, 1969. p. 20.

CODA. In: HARVARD Dictionary of Music. Segunda Edição. Cambridge: Havard University Press, 1969. p. 181.

DEHOUX, Vincent; GUILLAUME, Henri. Chasse, sexualité et musique: un arc musical des Pygmées Aka. In: DEHOUX, Vincent. Ndroje balendro: musiques, terrains et disciplines: textes offerts à Simha Arom. Paris: Peeters, 1995. p. 67-86.

DUKE, Daniel Joseph. Aka as a contact language: sociolinguistic and grammatical evidence. 2001. 170 f. Dissertação (Mestrado de Artes em Linguística) - University of Texas at Arlington, Arlington, 2001.

FORTE, Allen. Schoenberg as Webern: the three pieces for chamber orchestra, III (1910). Hillsdale: Pendragon Press, 2009.

FÜRNISS, Susanne. Centrafrique. Pygmées Aka (Chants de chasse, d'amour et de moquerie). Comentários no encarte. [S. l.]: Ocora Radio France; Arles: Harmonia Mundi, 1998. 
FÜRNISS, Susanne. Aka polyphony: music, theory, back and fourth. Analytical studies in world music. Oxford: Oxford University Press, 2006.

FÜRNISS, Susanne. Usages, variations, migrations: la harpe-en-terre d'Afrique centrale face à la classification universelle des instruments de musique. In: Rencontre annuelle du Comité international des musées et collections d'instruments de musique. Paris, 2011.

GILLIES, Malcolm. Bartók, Béla. Grove Music Online, Oxford, University Press, 2013. Disponível em: http://www.oxfordmusiconline.com/subscriber/article/grove/ music/40686pg2. Acesso em: 4 abr. 2013.

GRISEY, Gerard. Tempus ex machina: a composer's reflections on musical time. Contemporary Music Review, London, Harwood Academic Publishers, v. 2, p. 239-275, 1987.

HOMBERT, Jean-Marie. Linguistic implications of contacts between (agriculturalists) Bantu and Hunter-Gatherers. In: WORKSHOP METHODOLOGY IN LINGUISTICS PREHISTORY. Berlin, 2011. Disponível em: https://www2.hu-berlin.de/kba/events/mlp/ Hombert.pdf. Acesso em: 17 jun. 2014.

JOBIM, Antonio Carlos. The wonderful world of Antonio Carlos Jobim. [S, l.]: Warner Bros Records, 1965. 1 LP;

LESURE, François; HOWAT, Roy. Debussy, Claude. Grove Music, Oxford, Oxford University Press, 2013. Disponível em: http://www.oxfordmusiconline.com/subscriber/ article/grove/music/07353. Acesso em: 4 abr. 2013.

LIGETI, Györgi. [Entrevista cedida a] Benoît Delbec. Jazz Magazine, n. 484, set. 1998. Disponível em: https://ethaniverson.com/guest-posts/gyorgy-ligeti-interviewed-bybenoit-delbecq/.

LUNSQUI, Alexandre Roberto. The use of rhythm in contemporary music: Culture, Aesthetics, and Creativity. 2008. 45 f. Dissertação (Doutorado em Composição) Graduate School of Arts and Science, Columbia University, New York, 2008.

LUNSQUI, Alexandre Roberto. Areia II. New York. Edição do Compositor. 2009. 1 partitura. 78p.

MAHO, Jouni Filip. NUGL Online: the online version of the New Updated Guthrie List, a referential classification of the Bantu languages. [S. l.: s. n.], 2009. Disponível em: goto. glocalnet.net/mahopapers/nuglonline.pdf. Acesso em: 17 jun. 2014. 
MOURA, Eli-Eri. Processo Composicional de Desfragmentação. In: CONGRESSO DA ASSOCIAÇÃO NACIONAL DE PESQUISA E PÓS-GRADUAÇÃO EM MÚSICA, 16., Brasília. Anais [...]. Brasília, 2006.

PEYSER, Joan. To Boulez and Beyond. Lanham: Scarecrow Press, 2008.

SCHAPPER, Lauren. Ostinato. Grove Music Online, Oxford, University Press, 2013. Disponível em: http://www.oxfordmusiconline.com/subscriber/article/grove/ music/20547. Acesso em: 15 fev. 2014.

SCHOENBERG, Arnold. Drei Stucke fur Kammerensemble. Manuscrito do Compositor. 1910. Disponível em: http://www.schoenberg.at/compositions/warenkorb. php?typ=autograph\&id_werke=546\&id_quelle=1593. Acesso em: 4 abr. 2013.

SCHWARZ, K. Robert. Steve Reich: music as gradual process part II. Perspectives of New Music, v. 20, n. 1/2, p. 225-286, autumn 1981/summer 1982. Disponível em: http://www.jstor.org/stable/942414. Acesso em: 4 abr. 2013.

SOCHA, Eduardo. Tempo Musical em Theodoro W. Adorno. 2015. 328 f. Tese (Doutorado) - Programa de Pós-Graduação em Filosofia, Departamento de Filosofia, Letras e Ciências Humanas, Universidade de São Paulo, São Paulo, 2015.

SURFBOARD. Compositor: Antonio Carlos Jobim. Arranjo: Nelson Riddle. Manuscrito do arranjo. 1 Partituta. Disponível em: http://www.jobim.org/jobim/handle/2010/7140.

TAYLOR, Stephen Andrew. Ligeti, Africa and Polyrhythm. Journal of the Department of Ethnomusicology, Otto-Friedrich University of Bamberg, v. 45, n. 2, p. 83-94, 2003. Disponível em: http://www.stephenandrewtaylor.net/taylor-ligeti,africa.pdf. Acesso em: 1 abr. 2013.

VICTÓRIO, Roberto. Timbre e espaço-tempo musical. Territórios e Fronteiras, Cuiabá, v. 4, n. 1, p. 127-149, jan./jun. 2003.

WALKER, Paul. Codetta. Grove Music Online, Oxford, University Press, 2013. 